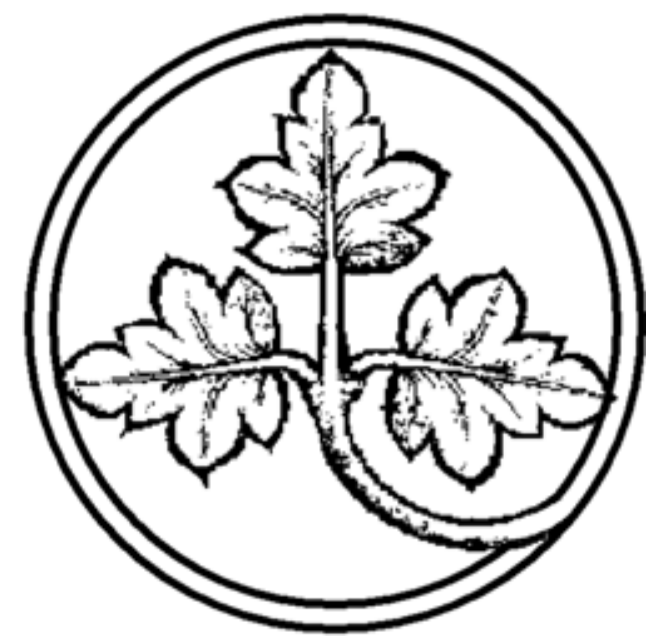

\author{
Preprints of the \\ Max Planck Institute \\ for Research on Collective Goods \\ Bonn \\ 2003/10
}

Governing the Egalitarians from Without The Case of the Internet

Christoph Engel 


\section{Governing the Egalitarians from Without The Case of the Internet}

\section{Table of Contents}

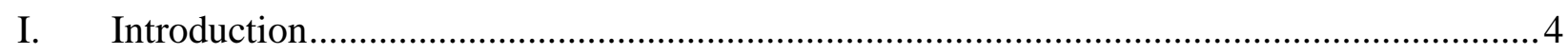

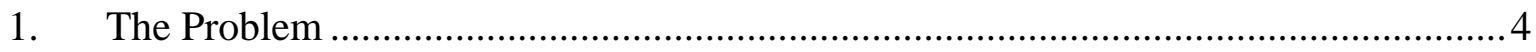

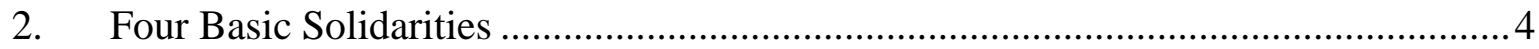

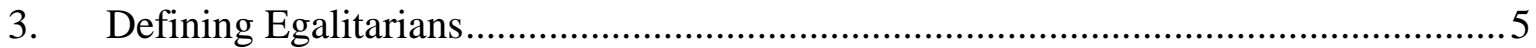

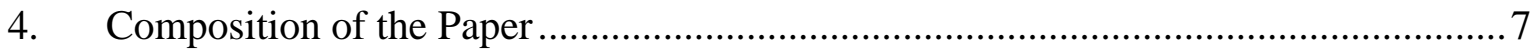

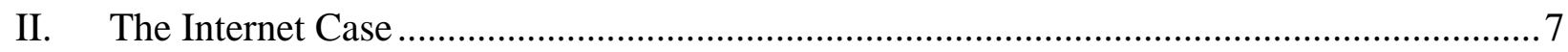

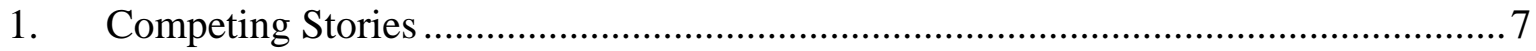

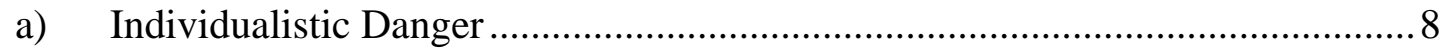

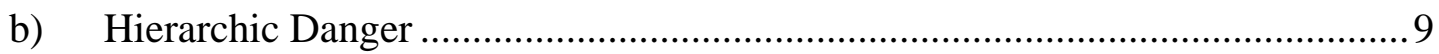

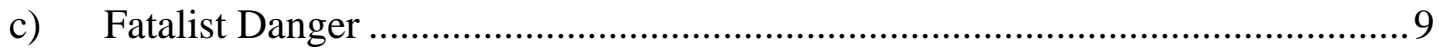

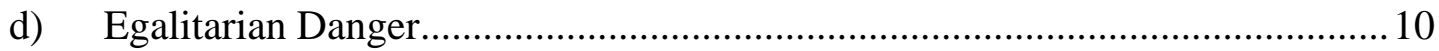

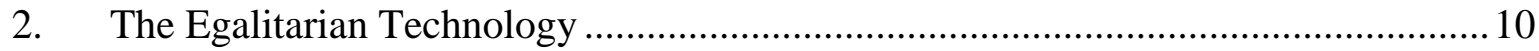

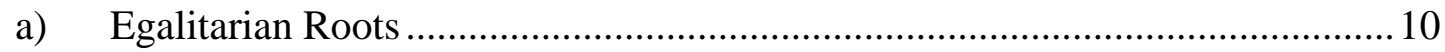

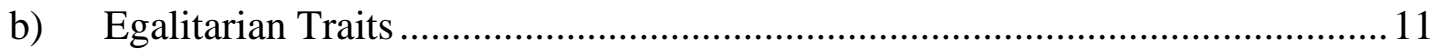

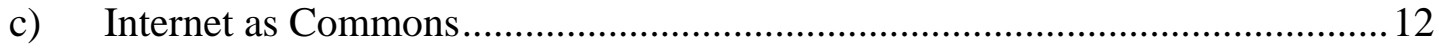

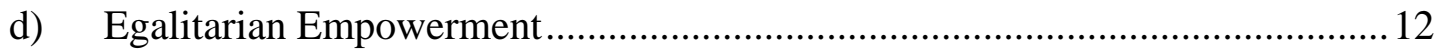

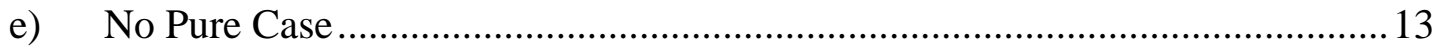

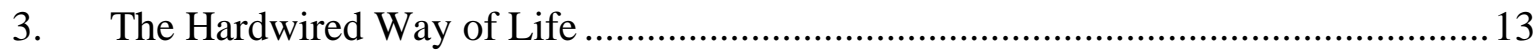

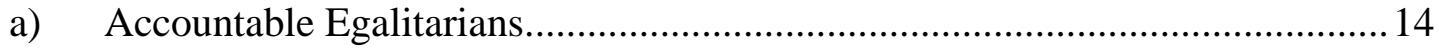

b) The Balancing Proof Technology …............................................................. 14

4. Copyright: The Bone of Contention with Individualists ......................................... 15

5. Content Regulation: The Bone of Contention with Hierarchists ...............................17

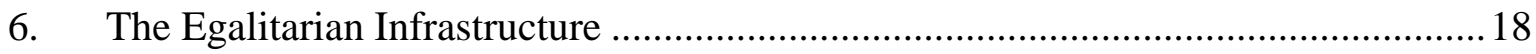

III. Deterministic vs. Probabilistic Governance..................................................................... 19

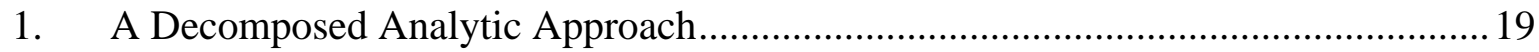

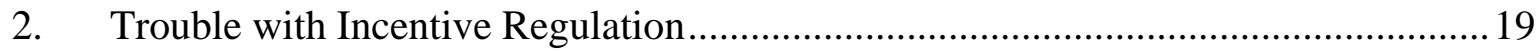

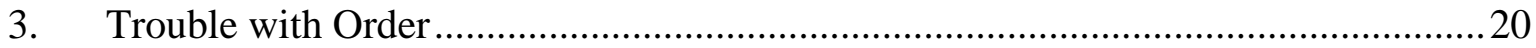

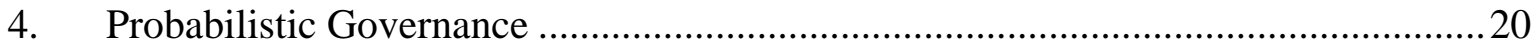

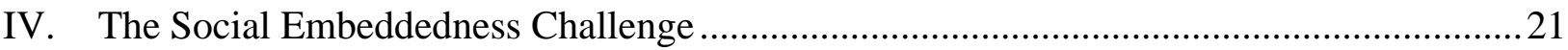

1. Social Embeddedness as a Restriction to Governance ............................................22 


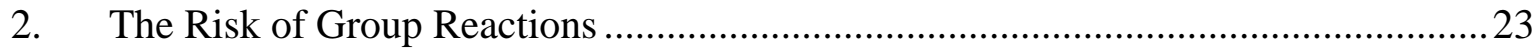

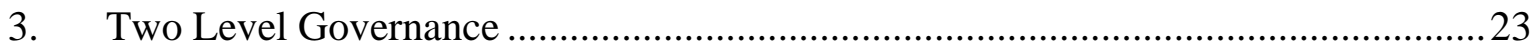

4. Exploiting Social Embeddedness for Governance Purposes......................................24

5. Collective Actors as Regulatory Targets.................................................................... 25

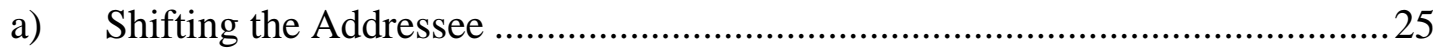

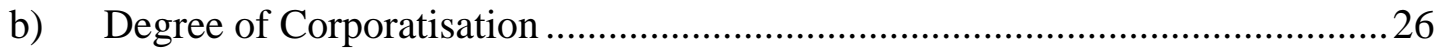

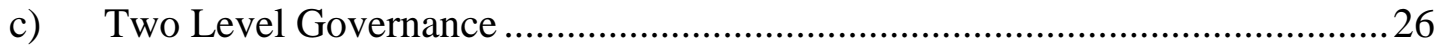

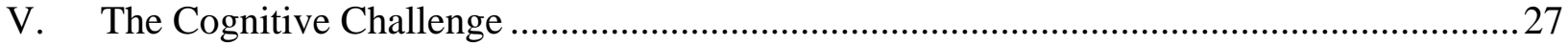

1. The Twofold Constructivist Challenge …................................................................ 27

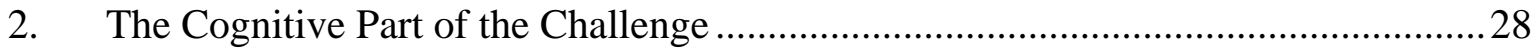

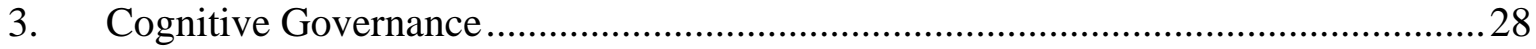

4. Exploiting Knowledge about Foreign Cognition .....................................................29

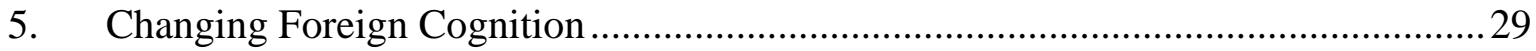

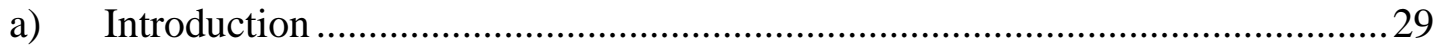

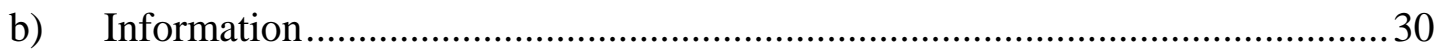

c) Transmitting Implicit Knowledge ................................................................. 31

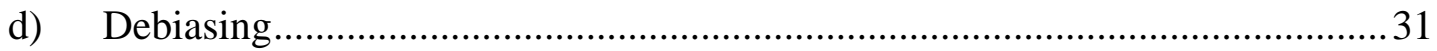

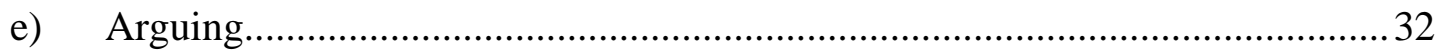

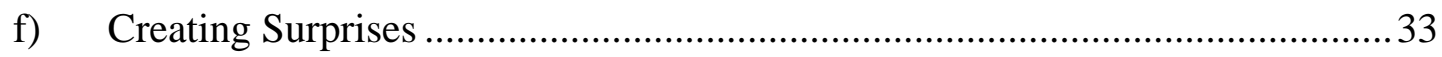

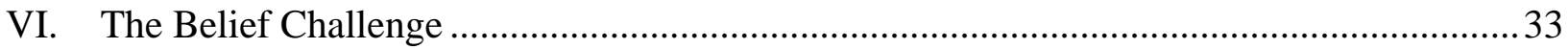

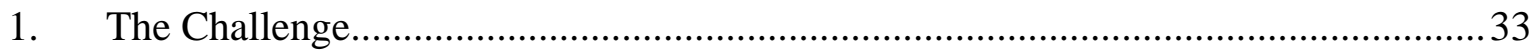

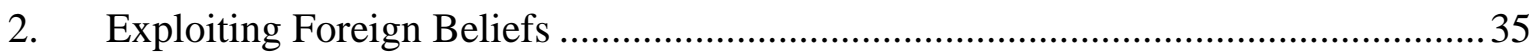

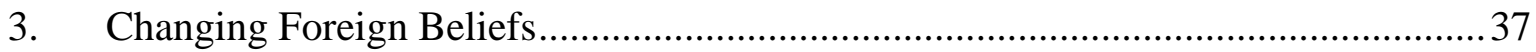

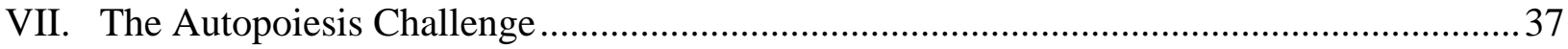

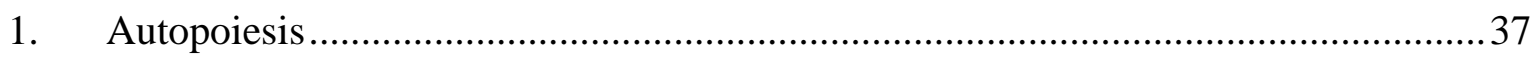

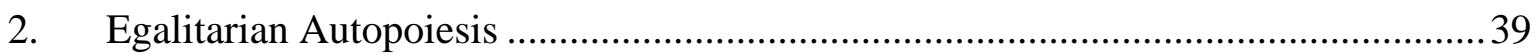

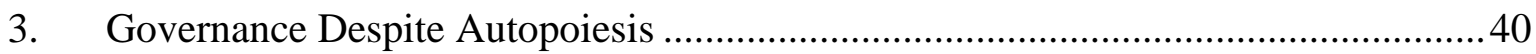

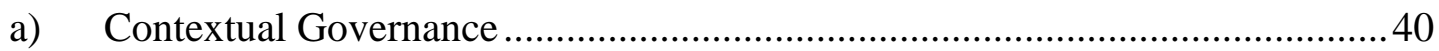

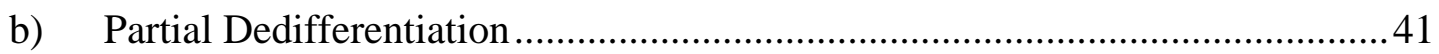

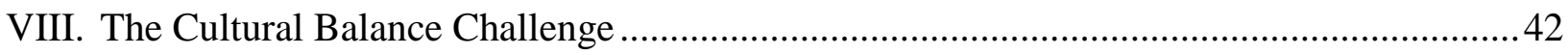

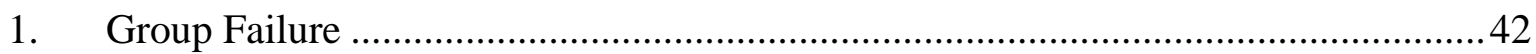

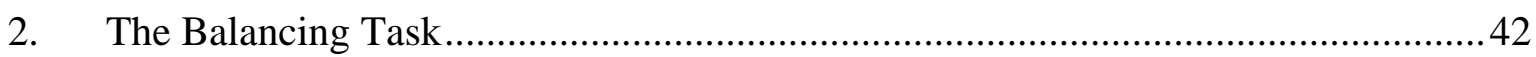

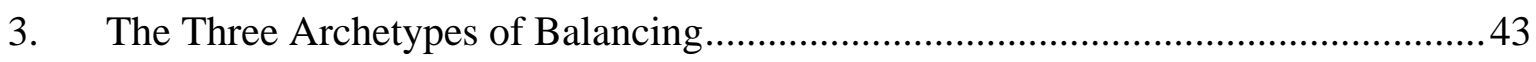

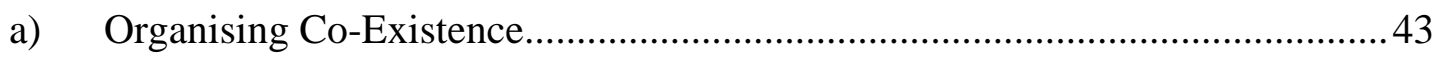

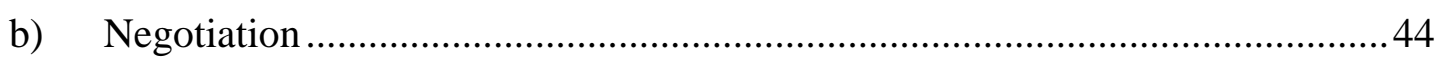

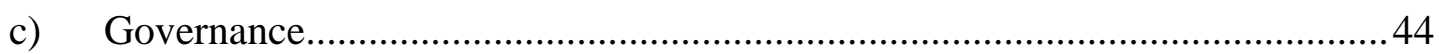




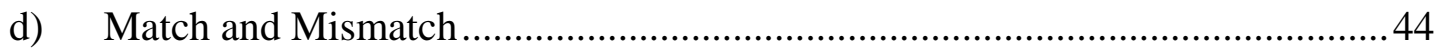

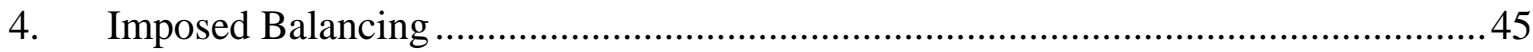

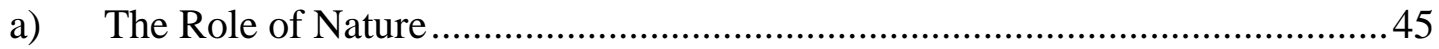

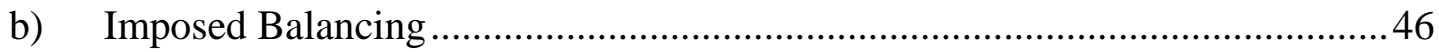

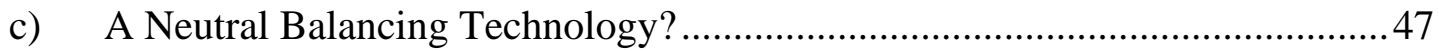

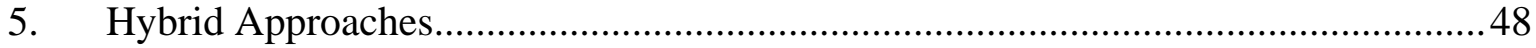

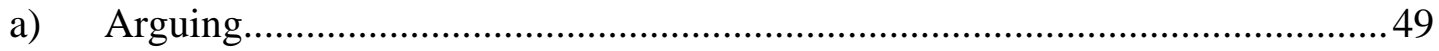

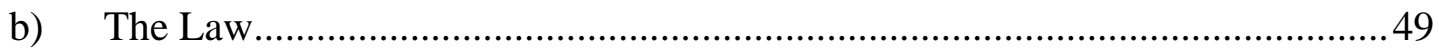

c) Addressing Individuals as Multiple Selves ...................................................50

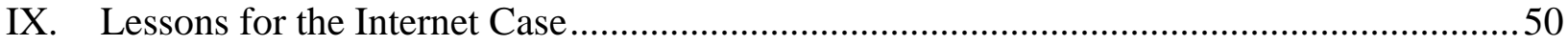

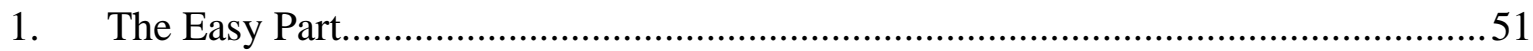

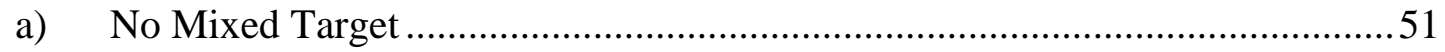

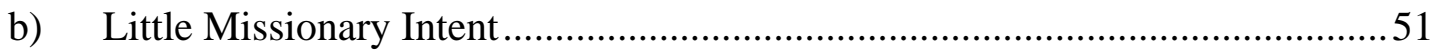

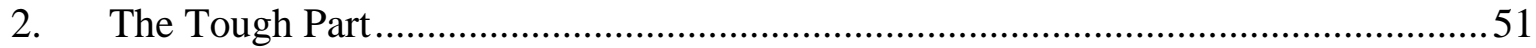

a) Governance of Net Architecture and Net Culture ...........................................52

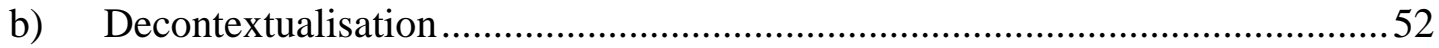

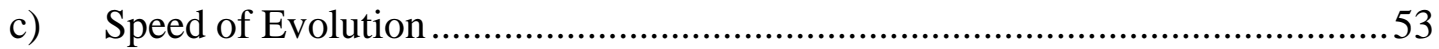

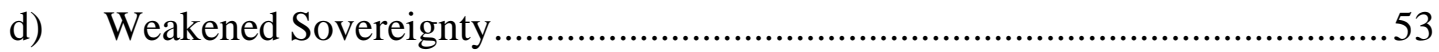

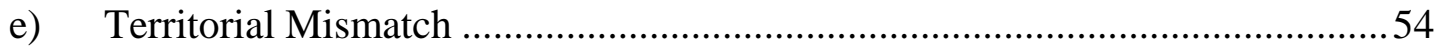

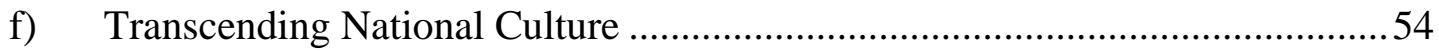

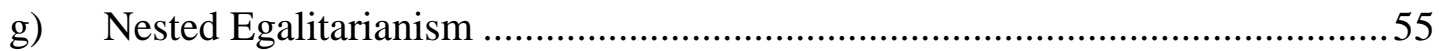

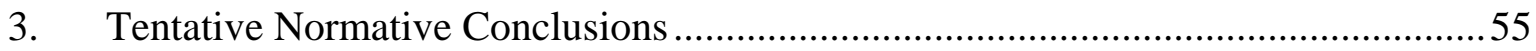

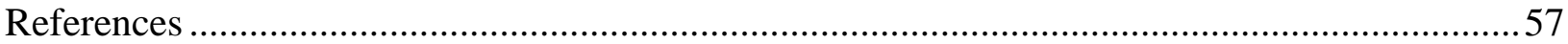

* Helpful comments by Martin Beckenkamp, Adrienne Héritier, Dieter Kerwer, Jörn Lüdemann, Stephan Magen, Chrysostomos Mantzavinos, Martin Rothfuchs and Marco Verweij and the linguistic trimming of the paper by Darrell Arnold are gratefully acknowledged. 


\section{Introduction}

\section{The Problem}

Regulators are not good at multi-tasking. Nobody would claim that regulators have neglected the Internet. There is a flurry of regulatory activity all over the world, ${ }^{1}$ and an almost intractable amount of academic work on Internet-related subjects. ${ }^{2}$ But most of this work is attracted by the global character of the Internet. Admittedly this is a serious challenge to regulation. ${ }^{3}$ But it is not the only one, and probably not even the most disquieting one. The Internet empowers libertarians to challenge the legal system from within. Most regulatory tools have a hard time in matching the tremendous speed of Internet evolution. And Internet use is almost entirely decontextualised, and therefore almost entirely without social control. ${ }^{4}$ Another of these largely overlooked challenges to governance is cultural. The Internet originated in the egalitarian culture of American university computer labs. ${ }^{5}$ Its architecture was shaped at that period. Up till now, many, if not the most key functions for Internet management have been held by people coming from that culture ${ }^{6}$. This paper basically makes three points: The egalitarian challenge to Internet governance has been largely overlooked. The challenge is serious, but not unmanageable. Yet regulators must use appropriate concepts to understand the challenge, and they must use a set of governance tools that deviates considerably from standard regulatory responses.

\section{Four Basic Solidarities}

At first sight, culture appears to be the amorphous result of historical contingency. From a sufficiently large distance, however, two factors help explain most of the cultural variance. Those academics pushing the approach even claim that these factors are exhaustive. ${ }^{7}$ Mary Douglas has dubbed them grid and group. ${ }^{8}$ The group parameter measures the extent to which an individual is incorporated into a larger social unit. The grid parameter characterizes the degree to which an individual's life is predetermined by heteronomous prescriptions. This is not the place to quarrel about the rigidity of the approach, nor to prove its correctness. Suffice it to show that the approach helps in understanding the egalitarians.

1 For an overview see GREWLICH Governance in Cyberspace (1999) .

2 The best overview is provided by Cyber Law Abstracts, http://papers.ssrn.com/sol3/JELJOUR_Results.cfm? form_name=journalBrowse\&journal_id=225 (Aug. 29, 2002).

3 My own contribution to this debate is ENGEL in Engel and Keller (2000).

4 More on these challenges, from the angle of governance by law, from ENGEL The Role of Law in the Governance of the Internet (2002c) .

$5 \quad$ For an impressive account see DeRTouzos What Will Be (1997) .

6 Despite all attempts from the exterior, this statement holds to these days, more from MUELLER Ruling the Root (2002) .

7 ThOMPSON, ELLIS and WiLDAVSKy Cultural Theory (1990) 13-15, 57 and passim.

8 DougLAs in Douglas (1982) 190-192 and 201-203. 


\begin{tabular}{|l|c|c|c|}
\hline \multicolumn{2}{|c|}{} & \multicolumn{2}{c|}{ group } \\
\cline { 2 - 4 } & high & low \\
\hline \multirow{2}{*}{ grid } & high & hierarchic & fatalistic \\
\cline { 2 - 4 } & low & egalitarian & individualistic \\
\hline
\end{tabular}

Cultural theory maps four basic solidarities to the grid group framework. High group and high grid make for hierarchists. Low group and low grid make for individualists. High grid and low group make for fatalists. And high group and low grid make for egalitarians. ${ }^{9}$ These are ideal types, cultural extremes so to speak. Real life illustrations are: for hierarchy, the high-caste Hindu villager; for individualism, the stock exchange trader; for fatalism, the unemployed East German skinhead; and for egalitarianism, the Greenpeace activist. ${ }^{10}$

\section{Defining Egalitarians}

Academic attempts to understand egalitarianism did not start with cultural theory. ${ }^{11}$ There has been considerable work on social movements, and in particular on totalitarianism. ${ }^{12}$ Lawyers might also see a parallel to integration theory. ${ }^{13}$ The normative underpinnings of egalitarianism have in recent years often been heralded under the title of communitarianism ${ }^{14}$. But cultural theory offers by far the most encompassing and precise picture of egalitarians. This picture is also particularly helpful in understanding the specific problem under review here, the egalitarian influence on the architecture and management of the Internet.

Egalitarian thinking starts from an implicit or explicit view of the world. Nature is thought to be ephemeral. "The world [...] is a terrifyingly unforgiving place and the least jolt may trigger its complete collapse". ${ }^{15}$ Resources are defined as fixed ${ }^{16}$. Since people can do nothing about them, their only available strategy is to decrease their needs ${ }^{17}$. The most optimistic vision egalitarians

9 ThOMPSON, ElLis and WiLDAVSKY Cultural Theory (1990) $6 \mathrm{f}$.

10 More illustrations from Ibid. Cultural Theory $8 \mathrm{f}$. and passim.

11 For a survey of doctrinal predecessors of cultural theory as such see Ibid. Cultural Theory 103-214.

12 Classic NEUMANN Behemoth (1942); ARENDT Totalitarianism (1951).

13 Its founder is SMEND in Smend (1968). The element of integration theory that comes closest is the stress it puts on community building by appealing to people's emotions.

14 See only ETZIONI Essential Communitarian (1998) ; for a German voice BRUGGER Liberalismus (1999)

15 ThOMPSON, ELLIS and WiLDAVSKY Cultural Theory (1990) 26.

16 Ibid. Cultural Theory 44.

17 Ibid. Cultural Theory 
are willing to consider is thus a zero sum game. One person's gain then inevitably is another person's loss. With a little trembling here and there, a negative sum game is even more likely $^{18}$."Nature is so precarious that the least inequality in the distribution of its resources will bring calamity"19 . Consequently, egalitarians stress risks, rather than opportunities ${ }^{20}$. They take thought for little else than the precarious future ${ }^{21}$.

While the egalitarians' view of nature is gloomy, their concept of man is strikingly optimistic. Human nature is seen as caring and sharing. ${ }^{22}$ "Humans are born good but are corrupted by evil institutions" ${ }^{23}$. "Human nature is not only good but is also highly malleable". ${ }^{24}$

As everybody else, egalitarians tend to select information such that it confirms their view of the world. They highlight events apparently proving that the world is getting out of control, ${ }^{25}$ and that the blame can be placed on governmental or market intervention. ${ }^{26}$ Thus "egalitarians are not in the business of delivering. Their business is criticizing". ${ }^{27}$ By doing this, they also create internal cohesion. ${ }^{28}$ Egalitarians thus need the competing ways of life as something to be pitted against. ${ }^{29}$ "Solidarity is maintained by portraying external forces as monstrous, and by accusing deviants of secretly importing evil ways [...] to corrupt the membership". ${ }^{30}$ Egalitarians do thus "maximize their transactions by keeping their group apart from others, ${ }^{31}$ by constructing a 'wall of virtue. 32

Internally, egalitarians govern by conviction, not coercion. ${ }^{33}$ They aim at bringing a learning process about, relying on "exposure (of the failing of the other solidarities) and revelation (good and bad in black and white)" ${ }^{\prime 34}$. Among themselves, they stress symmetry and accountability. ${ }^{35}$ "Leadership is resisted and equality prized". ${ }^{36}$ By equality, they do not mean equality of opportunity, but of outcome. ${ }^{37}$ Moreover, those at the bottom are supposed to have access to vital knowledge that is inherently inaccessible to those on the top. ${ }^{38}$

18 Ibid. Cultural Theory 44, see also 29.

Ibid. Cultural Theory 44.

Ibid. Cultural Theory 64.

Ibid. Cultural Theory 11.

THOMPSON in Engel and Keller (2000) 131.

ThOMPSON, ELLIS and WILDAVSKY Cultural Theory (1990) 34.

Ibid. Cultural Theory .

THOMPSON in Engel and Keller (2000) 125.

THOMPSON, ELLIS and WILDAVSKY Cultural Theory (1990) 59.

Ibid. Cultural Theory 10.

Ibid. Cultural Theory 9.

Ibid. Cultural Theory 4.

Ibid. Cultural Theory 60.

Ibid. Cultural Theory 12.

Ibid. Cultural Theory 9.

THOMPSON in Engel and Keller (2000) 125.

Ibid. in

TRANVIK, THOMPSON and SELLE in Engel and Keller (2000) 165.

THOMPSON in Engel and Keller (2000) 127.

TRANVIK, THOMPSON and SELLE in Engel and Keller (2000) 165.

THOMPSON in Engel and Keller (2000) 121 note 5. 
Consequently, egalitarians have a strong preference for one institutional arrangement: the common pool resource. ${ }^{39}$ In terms of technology, egalitarians "prefer small-scale and emancipating technologies: technologies that [...] are likely to equalize differences". ${ }^{40}$

\section{Composition of the Paper}

Ideal types never fully match reality. But interpreting reality against the backdrop of them casts a lot of new light on the Internet case (as shall be shown in section II below). It clarifies why the two classic regulatory approaches are not likely to be very effective: regulation by incentive and regulation by order. There are several ways of describing the challenges for governance inherent in egalitarian addressees. The most generic demonstrates that governance must be probabilistic rather than deterministic (section III). A somewhat more specific interpretation sees the challenge in the social embeddedness of behaviour characteristic of the members of egalitarian actors (section IV). Another interpretation stresses the constructivist character of the challenge. It comes in two parts. The first is cognitive (section V). The second part is the specific egalitarian belief system (section VI). A fifth approach picks a key element from systems theory and turns it into a governance challenge: autopoiesis (section VII). The last interpretation ties all these elements together and sees them as what one might call the 'cultural balance challenge' (section VIII). This paper concludes by drawing lessons for the Internet case from these various interpretations of the egalitarian challenge (section IX).

\section{The Internet Case}

\section{Competing Stories}

Cultural theory is constructivist. ${ }^{41}$ Constructivism would violate its own intellectual basis if it pretended to know how a social phenomenon like the Internet "really" is. Neither could it pretend to have conceptual certainty about the normative foundations for governing the Internet. ${ }^{42}$ Put differently, cultural theory starts from fundamental conceptual and normative relativity. ${ }^{43}$ But cultural theory does not deny reality. In theoretical jargon: it adheres to soft, not to hard constructivism. Reality can indeed surprise observers and actors, and force them to change their

39 Ibid. in 121 ; on such institutional arrangements see OsTROM Governing the Commons (1990); OsTROM, DiETZ, Dolsak, STERn, StOnich and WeBer The Drama of the Commons (2002).

40 TrANVIK, THOMPSON and SELLE in Engel and Keller (2000) 165.

41 See only ThOMPSOn, ELLIS and WILDAVSKY Cultural Theory (1990) xiii: "The subject of this book is meaning. We are interested in how individuals confer meaning upon situations, events, objects, relationships - in short, their lives".

42 The opposite is made explicit in THOMPSON in Engel and Keller (2000) ; see also TrANVIK, THOMPSON and SELLE in Engel and Keller (2000).

43 From a governance perspective see ENGEL in Rechtstheorie (2001b). 
minds. ${ }^{44}$ But cultural theory insists that no observer can have certainty about reality. It thus adheres to the epistemological view that reality can only be seen through the lens of theory driven hypotheses. ${ }^{45}$ For cultural theory, it therefore does not come as a surprise that a social phenomenon as complex and rich as the Internet can be interpreted in very different ways. It therefore is not difficult to tell stories that see the basic danger of the Internet in the empowerment of the individualists (section a below), the hierarchists (section b) or the fatalists (section c). But this paper does not only maintain that the egalitarian danger is one among many. To the degree possible from a soft constructivist starting point, it is convinced that, for the time being, the egalitarian danger looms largest (section d).

\section{a) Individualistic Danger}

Many observers see the Internet as a gigantic empowerment machine for profit-seeking firms. The claim is that the Internet bounces the production frontier up to their benefit. ${ }^{46}$ "The invisible hand, through commerce, is constructing an architecture that perfects control - an architecture that makes possible highly efficient regulation". ${ }^{47}$ Via the Internet, individualists can to a considerable degree even free themselves from the need for hierarchic support. For now they can generate and enforce their own institutions. It is no longer necessary for them to rely on the democratically controlled legislator, or on the court system, to shape the institutional framework for markets as they will. Copyright management systems, ${ }^{48}$ electronic watermarks, ${ }^{49}$ click - wrap contracts, ${ }^{50}$ and electronic money illustrate the potential. ${ }^{51} \mathrm{~A}$ firm is not only able to exploit the Internet to escape regulatory authority. ${ }^{52}$ It can also use it to directly mine its customers. This is behind the concerns of consumerists. ${ }^{53}$ Consumers risk having their personality checked out without even noticing, ${ }^{54}$ or being paternalistically directed without ever having asked to be. ${ }^{55}$ Consumers are left with little more than self help mechanisms, ${ }^{56}$ i.e. some forms for building electronic countervailing power.

44 Cultural theory even has a theory of surprises as one of its building blocks, see THOMPSON, ELLIS and WILDAVSKY Cultural Theory (1990) 3 and 69-75.

45 Basic ALBERT Kritische Praxis (1978)

46 TrACHTMAN in Indiana Journal of Global Legal Studies (1998) at note 12 and passim.

$47 \quad$ LESSIG Code (1999) 6.

48 Comprehensive BECHTOLD Digital Rights Management (2002)

49 KATZENBEISSER and PETITCOLAS Information Hiding (2000)

50 RADIN and WAGNER in Chicago Kent Law Review (1998).

51 MÜLLER Elektronisches Geld (2002)

52 More on this from TRANVIK, THOMPSON and SELLE in Engel and Keller (2000) 179.

53 For an overview see WALDENBERGER in Hoeren and Sieber (2000).

54 RealNetwork secretly collected information about the listening habits of customers who bought Real Jukebox, including listening to CDs on their computers BENKLER in Colorado Law Review (1999) at note 221.

55 This is a standard criticism of commercial filtering systems. They tend to have many "false positives", and they typically do not make their filtering policy transparent, LESSIG and RESNICK in Michigan Law Review (1999) 425; NATIONAL ReseARCH COUnCIL Pornography (2002b) 12.1.2. 


\section{b) Hierarchic Danger}

A competing story runs under the heading “Athens or Orwell”. It is a remake of the well-known Big Brother story. ${ }^{57}$ Economically speaking, the Internet does not only extend the production frontier of firms, but also of governments. ${ }^{58}$ Authoritarian regimes all over the world are strengthened, as demonstrated by cases like China or Cuba. ${ }^{59}$ Computer-aided regulation is no bounty for addressees ${ }^{60}$. Government can control gateways, ${ }^{61}$ identify individual recipients ${ }^{62}$ and the character of the content. ${ }^{63}$ It can even change the architecture of the Net in the interest of making it more "regulable". ${ }^{64}$ Moreover, the Internet provides the government with highly vulnerable regulatory targets, in particular the technical intermediaries. ${ }^{65}$ This view will also point to the military origin of the Internet, meant to keep communication alive even after a successful atomic strike.

The hierarchic and the individualistic danger can even be compounded, resulting in an opaque, but powerful conglomerate of firms and governments. ${ }^{66}$ A graphic example is the following: a radical minority Senator forced Congress to add the Communications Decency Act to the overhaul of the telecommunications legislation. As expected by most, the courts struck the statute down. But industry was triggered to develop fairly powerful filtering technology. This technology cannot only be used by parents to protect their children, but also by an authoritarian government. ${ }^{67}$

\section{c) Fatalist Danger}

A third group of observers tells a story of fatalist danger originating from the Internet. They point to pornographers, ${ }^{68}$ Nazi groups, ${ }^{69}$ gamblers, ${ }^{70}$ and criminals all empowered by the Inter-

57 See Dertouzos What Will Be (1997) 293, adding some sceptical remarks; see also BoYLE in University of Cincinnati Law Review (1997) 178 and passim.

58 TRACHTMAN in Indiana Journal of Global Legal Studies (1998) at note 12.

59 More from YURCIK and TAN The Great (Fire)Wall of China. Internet Security and Information Policy Issues in the People's Republic of China (1996); KALATHIL and BoAs Internet and Autoritarian Regimes (2001)

60 Kesan and Gallo Neither Bottom-Up Nor Top-Down. A Tacit Public-Private Cooperative Solution for Internet Regulation (2001) 54.

61 LESSIG and RESNICK in Michigan Law Review (1999) 415; MAYER in European Journal of International Law (2000) 161: currently, 45 countries restrict Internet access.

62 LeSSIG and ReSNICK in Michigan Law Review (1999) 404.

63 Ibid. in 404 f., 409 f., 411.

64 LESSIG Code (1999) 43 and passim.

65 LESSIG and RESNICK in Michigan Law Review (1999) $403 \mathrm{f}$.

66 See again the quote from LESSIG Code (1999) 6: "The invisible hand, through commerce, is constructing an architecture that perfects control - an architecture that makes possible highly efficient regulation”.

67 The story is told by BENKLER in European Journal of International Law (2000) 176; for a further story see BENKLER in European Journal of International Law (2000) 182.

68 See only NAtionAl ReseArCh Council Pornography (2002b)

69 PENFOLD in Journal of Information, Law and Technology (2001); SIEBER in Zeitschrift für Rechtspolitik (2001); NATIONAL RESEARCH COUNCIL Global Networks and Local Values (2002a) 106-132; ENGEL in Multimedia und Recht (2003b).

70 Schwarz in Berkeley Technology Law Journal (1999); Clarke, DeMPSEY, OoI and O'ConNOR Internet Gambling (2001) 
net. Again, the story is not without factual backing. As is often repeated, the nucleus of the Internet, ARPANET, has been designed such that even the violent interruption of communication lines could not stop communication altogether. ${ }^{71}$ This is why Internet traffic is packet switched. All communication is cut into small morsels, seeking their way separately through a worldwide interconnected network. This makes interception of Internet traffic practically impossible. If users want even better protection, they can encrypt their traffic, ${ }^{72}$ and they can use anonymizers. ${ }^{73}$ All these features allow fatalists to escape outside control with very little effort.

\section{d) Egalitarian Danger}

As admitted at the outset, none of these stories is false. But they all overlook another, the egalitarian danger. This danger looms at least as large as the others. It stems from the fact that the Internet has not only largely been shaped by egalitarians (section 2). They have even hardwired their way of life in the Internet architecture (section 3). This general point can be illustrated by two salient bones of contest. Copyright opposes egalitarians with individualists (section 4), content regulation does the same between egalitarians and hierarchists (section 5). But the competing (active) ${ }^{74}$ ways of life should take care when they defend their position vis-à-vis the egalitarians. They might well have the power to fix their problems once and forever. But such radical responses would not be in their own long term interest. For they need the egalitarian base of the Internet as an infrastructure, allowing themselves to thrive (section 6).

\section{The Egalitarian Technology}

The Internet does not only have egalitarian roots (section a). It conserves many egalitarian traits (section b). The Internet is organised along the egalitarians' preferences, namely as a commons (section c). It is a machine for egalitarian empowerment (section d). This is at least, how the facts can be stylised. But even if one admits for some caveats, the egalitarian elements remain strong (section e).

\section{a) Egalitarian Roots}

The military prelude notwithstanding, the evolution of the Internet has been driven by engineers basically uncontrolled by either government or market. The other ways of life had different, less viable plans for transnational data transfer. They realized the potential of the Internet only when

71 On the history of the Internet see NATIONAL RESEARCH COUNCIL Global Networks and Local Values (2002a) 23-45.

72 Comprehensive NATIONAL RESEARCH Council Cryptography (1996)

73 See only FrOOMKIN in University of Pittsburgh Journal of Law and Commerce (1996).

74 Fatalists by definition take their environment as is. Accordingly there is no such thing as a fatalist Internet policy, pitching fatalists and egalitarians against each other. In cultural theory, fatalism is therefore called the passive way of life, as opposed to the other three active ways. 
it was already in place. ${ }^{75}$ This allowed the techies to give the network their flavour. Not surprisingly, this flavour was basically egalitarian, because many of the decisive steps were taken in University computer labs. ${ }^{76}$ And even those computer activists working in industry basically shared the same professional culture. ${ }^{77}$

\section{b) Egalitarian Traits}

The Internet does not only have an egalitarian history. It also preserves many egalitarian traits. The most visible is a borderline case. The open source movement, and Linux in particular, does not concern the Internet itself, but a major condition necessary for the Internet to become effective. The open source movement has attracted a lot of academic interest, because it radically deviates from the business model of the traditional economy. ${ }^{78}$ In line with this, quite a lot of the business done over the Internet is best characterized by the idea of a gift economy. ${ }^{79}$ The core electronic product is often given away for free, aiming at voluntary contributions from users for the production costs, or at sales on ancillary markets. ${ }^{80}$ Many of those driving the evolution of the Internet think that scarcity is not the problem, but that, at most, the unpredictable rise of demand is. $^{81}$

Internet activists do herald their egalitarian conviction. ${ }^{82}$ As is characteristic for egalitarians, Internet activists are tied together by a common enemy, be it Microsoft or big business more generally. This explains the emotional, sometimes even violent reaction to what the activists have called spam, i.e. unsolicited e-mail. ${ }^{83}$ The vigorous response to spam is all the more indicative if compared to virus attacks. Both challenges can best be parried by installing filters. In the case of viruses, most Internet users have long accepted this, and they grudgingly update their virus scanners routinely. Spam is easier to filter, and its nuisance value is by far smaller than that of viruses. Nonetheless the emotional reactions are reserved to spam. It originates from the identity defining enemy. Finally, egalitarianism is present in social norms for Internet use, as epitomized by the "netiquette" 84 .

75 See again TrAnviK, ThOMPSON and SELle in Engel and Keller (2000) 178; NATIONAL RESEARCH CounCIL Global Networks and Local Values (2002a) 23-45.

76 REIDENBERG in Texas Law Review (1998) 571.

77 Impressive in its richness DeRTOUZOS What Will Be (1997)

78 From the rich literature see LERNER and TIROLE Open Source (2000); BESSEN Open Source (2001); HOLTGREWE in Allmendinger (2001); KUAN Open Source (2001); MCGOWAN in University of Illinois Law Review (2001); HunTER Digital Anticommons (2002); REDDY and EVANS Open Source (2002)

79 KELLY New Economy (1998) 60-62.

80 Ibid. 63-64.

81 Characteristic FARBER in Engel and Keller (2000)

82 Characteristic the "inaugural speech" of the German at large member of ICANN, ANDY MÜLLER-MAGUHN, http://www.datenreisen.de/papers/Regierungserklärung.html (10.6.2002).

83 For a definition see http://www.cli.org/selford/Spam.htm (31.8.2002); on a key event see PERRITT in Berkeley Technology Law Journal (1997) 438 s.

84 HAmbridge Netiquette Guidelines (1995) ; critical RAdiN and WAGNER in Chicago Kent Law Review (1998) at note 44. 


\section{c) Internet as Commons}

Cultural theory would expect organisation to follow the predominant belief system. The characteristic institutional arrangement for egalitarians is a jointly managed commons. ${ }^{85}$ And the Internet does indeed have many traits of a commons. ${ }^{86} \mathrm{~A}$ closer look is even more elucidating. On the Internet, it is not unusual for data packets to make large geographical detours. If a German national wants to retrieve information from a German server, it is well nigh possible that many of the data packets go via the U.S. This can make sense, since, due to its technical history, the backbone capacity in the U.S. is larger than anywhere else in the world. Moreover, once a user pays a fee to his local Internet Service Provider, he can access any web or e-mail server all over the world. Functionally, the Internet is thus indeed a commons. Technically and economically, this is different however. For the local Internet Service Provider must himself buy the right to transmit traffic to parts of the backbone. The routers managing Internet traffic will only let those data packages pass that have paid for transport via the originating Internet Service Provider. ${ }^{87}$ The functional commons thus results only from the high redundancy of the commercially organised backbone network.

\section{d) Egalitarian Empowerment}

"By its very nature as a child of the industrially wealthy and democratic nations of the world, the information market place will act as a gigantic flywheel of egalitarian customs and habits". 88 "Egalitarians [...] foresee this free-floating system of zic zac electronic paths as a technology that is likely to equalize differences, since it is designed to circumvent gates and gate-keepers". ${ }^{8}$ "When are all these technologies finally going to let us hear from the voiceless millions of this earth?"90 These citations by Yehudi Menuhin and others highlight how much the Internet serves as a machine for egalitarian empowerment.

Many of its features add to the effect. The very basic technical protocol TCP/IP is radically egalitarian. Irrespective of contents, sender or receiver, it cuts all communication into small pieces that are treated equally. Since these bits are so small, the least bandwidth allows for at least some Internet communication. Information is available everywhere in the world. Receivers need no longer go through some technical or economic gate to get access to information. No more than a standard personal computer and flat rate access to the Internet is needed to become an information provider. This allows for radical decentralization, disempowering both hierarchy

85 See the rich material provided by OsTROM Governing the Commons (1990)

86 More from KollOCK and SMITH in Herring (1996); GUPTA, STAHL and Whinston in Amman and Berc Whinston (1997); HUNTER Digital Anticommons (2002)

87 More from European Commission, Internet Network Issues, CEPT, ETNO \& EICTA WTSA-2k doc. (00)122 Rev. 002 of September 11, 2000; see also KESAN and SHAH in Washington University Law Quarterly (2001).

88 DERTOUZOS What Will Be (1997) 294.

89 TrANVIK, THOMPSON and SELLE in Engel and Keller (2000) 180.

90 YeHudi Menuhin, cited to Dertouzos What Will Be (1997) 284. 
and market. ${ }^{91}$ Most important for egalitarians is the fact that the Internet makes organising groups easier than ever before. Economically speaking, the organisation cost drops to nearly zero. This strongly reduces the traditional comparative disadvantage for social movements vis-àvis stricter forms of organisation. Put in the influential terminology of Mancur Olson: These interests are no longer diffuse. ${ }^{92}$ Civil society becomes a much more realistic option. Neighbourhood can be virtual. ${ }^{93}$ Community no longer presupposes propinquity. ${ }^{94}$ Civil society has not hesitated to seize the opportunity. The Internet has been decisive in striking down the multilateral agreement on investment. ${ }^{95}$ Internet activists have brought the case of Chiapas in Mexico to the attention of the world. ${ }^{96}$ Others have used the Internet to de-stabilize the belligerent regimes in Bosnia and Kosovo. ${ }^{97}$

\section{e) No Pure Case}

As impressive as all these observations are, they should not be misunderstood. As cultural theory posits, the four solidarities are ideal types. Reality nearly never entirely obeys one of them. The Internet is no exception to this. Even at its egalitarian core, non-egalitarian elements are to be found. Linux uses copyright to protect itself against outsiders. And IBM is part of the Linux coalition. ${ }^{98}$ A reputation gain within Linux is valuable human capital on the labour markets. ${ }^{99}$ Linux has surrounded itself with professional service providers on the periphery, managing the interface between the egalitarian core and a more commercial environment. ${ }^{100}$ Thus pure egalitarianism is not the issue; an unusually strong egalitarian component is. Understanding the pure theoretical case is, however, the best preparation for effectively reacting to this egalitarian component.

\section{The Hardwired Way of Life}

Each of the three active ways of life has an important contribution to make. The mere fact that the Internet creates opportunities for egalitarians is thus not normatively problematic. Egalitarians are no less accountable than hierarchists or individualists (section a below). What creates a problem however, is that, to a considerable degree, the egalitarian way of life is embedded in the technology of the Internet. This makes it burdensome to balance of the egalitarian way of life with the competing ones (section b).

91 Many of these traits are highlighted by THOMPSON in Engel and Keller (2000) 123.

92 OLSON Collective Action (1965)

93 Dertouzos What Will Be (1997) 157-160.

94 THOMPSON in Engel and Keller (2000) 123.

95 More from National RESEARCh Council Global Networks and Local Values (2002a) 81.

$96 \quad$ More from Ibid. Global Networks and Local Values 86.

$97 \quad$ More from Ibid. Global Networks and Local Values 94.

98 ROBERT MNOOKIN pointed me to both facts.

99 LERNER and TIROLE Open Source (2000)

100 More from HolTGREWE in Allmendinger (2001) $416 \mathrm{f}$. 


\section{a) Accountable Egalitarians}

Outsiders sometimes misperceive egalitarians as unruly anarchists. It is true that they coordinate neither via formal institutions nor via exchanging goods on markets. But they have their own means of coordination, and these means are no less accountable than their hierarchic or individualist counterparts. They stress informal rather than formal institutions, relying on social norms and identity. They police these norms by shaming ${ }^{101}$ and expulsion. ${ }^{102}$ Economists might get a better sense of what is meant by these concepts if they link them to the well known terms of exit and voice. ${ }^{103}$ What Albert Hirschman saw as ways for members to control the management of an organisation are now turned upside down. Shaming is voice by the group against the individual. Expulsion is exit imposed on a member by the collectivity. In practical terms, Internet egalitarians have taken up issues like spam, against which a.c.e.n.a. intervenes ${ }^{104}$, or child pornography, which is chased by the Cyberangels. ${ }^{105}$

\section{b) The Balancing Proof Technology}

Cultural theory defines the normative goal as follows: no way of life is ever to fully win out over its competitors. Since each solidarity highlights elements of nature and solidarity that are really out there, none of them should be allowed to be in a safe harbour. ${ }^{106}$ In accord with that perspective, a frequent observation in the academic discourse on the Internet becomes dramatic. These observers claim that on the Internet, power is embedded in technology. ${ }^{107}$ Technical "code is law". ${ }^{108}$ Governance is hardwired. ${ }^{109}$ Due to the history of the Internet, this hardwiring favours egalitarianism to a considerable degree. ${ }^{110}$

Hardwiring implies excessive rigidity. Policy changes require that the infrastructure be rebuilt. ${ }^{111}$ "Problems can be programmed away". ${ }^{112}$ Code is self-enforcing, and thereby free from any

101 SCHEFF in Sociological Theory (2000); cf. also BOULDING in Atlantic Economic Journal (1987).

102 GRUTER and MASTERS Ostracism (1986) ; see also RADIN and WAGNER in Chicago Kent Law Review (1998) 1317.

103 As coined by HIRSCHMAN Exit voice (1970)

104 More from PERRITT in Berkeley Technology Law Journal (1997) 438-440.

105 http://www.cyberangels.org/ (31.8.2002); see also EGAN in Suffolk University Law Review (1996).

106 THOMPSON, ELLIS and WILDAVSKY Cultural Theory (1990) 83-86.

107 BOYLE in University of Cincinnati Law Review (1997) 177 and passim.

108 LESSIG Code (1999) 6.

109 REIDENBERG in Emory Law Journal (1996); BOYLE in University of Cincinnati Law Review (1997) $177 \mathrm{f}$; REIDENBERG in Texas Law Review (1998) 555 and 586; LESSIG Code (1999) 15-17.

110 Cf. TranviK, Thompson and Selle in Engel and Keller (2000) 166: „the technological design that the winning solidarity has locked us all into"; THOMPSON in Engel and Keller (2000) 126.

111 REIDENBERG in Emory Law Journal (1996) at note 61; cf. also REIDENBERG in Texas Law Review (1998) 587: „Policymakers must be involved early in the development phases of new technologies to assure that options and flexibility are maximised”.

LESSIG Code (1999) 13. 
implementation deficit. ${ }^{113}$ Even resistance often comes too late. For code is often regulation that goes unnoticed. ${ }^{114}$

The point should not be overstated, however. Only the technological basis is hardwired, not the complementary social infrastructure of Internet egalitarians. Moreover, the way of life as such is not hardwired, but only an opportunity structure that is advantageous for egalitarian selforganisation.

\section{Copyright: The Bone of Contention with Individualists}

What does this mean in more practical terms? By way of illustration, one of the bones of contention between Internet egalitarians and individualists, and with hierarchists, shall be portrayed in somewhat greater detail. Both conflicts go to the core of the competing ways of life. Disabling copyright essentially forces individualists not to use their defining way of coordinating behaviour, the market. Likewise, disabling the power of government to control Internet contents is paramount to disabling the defining demand of hierarchists, internal sovereignty ${ }^{115}$.

The most primitive market needs at least three institutions in order to work: Property rights, contract, and an enforcement mechanism. ${ }^{116}$ For digital products like music recordings, the Internet might make it possible to do away with them to a considerable degree. For the cost of distributing such products falls to trivial sums. Artists no longer need the big music companies as intermediaries. Via the Internet, they can reach their public directly. They can decide themselves whether they are content with giving recordings away for free if this entices enough listeners to contribute in different ways to the production costs. Tickets to live performances, or the purchase of CDs, as some sort of a premium service, are the most popular options. ${ }^{117}$

The music industry took this as casus belli. It sued MP3.com, which offered the digitally compressed contents of music CDs for download. ${ }^{118}$ After the court case was won, one of the big players in the music industry bought MP3.com and thereby made it mute. ${ }^{119}$ Napster used a more intelligent scheme. The company did not itself offer music files for download. It only organised file sharing among its customers. But this did not help the company either. It also got sued and

113 On the implementation problem see WINTER Vollzugsdefizit (1975); MAYNTZ Implementation (1980)

114 BERMAN in University of Colorado Law Review (2000) 1265.

115 Actually, this might not even be the most frightening attack by Internet egalitarians to governmental power. Under less public scrutiny, a number of hacking activists is fighting cyber crime investigators and the secret services by technical means, http://www.guardian.co.uk/print/0,3858,4472989-104917,00.html (22.9.2003). For greater detail see ENGEL in Depenheuer, Engel and von Danwitz (2002b) 47-50.

117 More from IAN Internet Debacle (2002b); IAN Fallout (2002a); KU in University of Chicago Law Review (2002); see also 114 F Supp 2d 896, I B 3 - Napster I.

11892 F Supp 2d 349.

119 Yu in FindLaw's Legal Commentary (2002). 
lost its case. ${ }^{120}$ Recently, the music industry has also started suing Internet Service Providers for giving their clients access to music file sharing systems from abroad. ${ }^{121}$

The music industry also got support from the legislator. The U.S. Digital Millenium Copyright Act 1998 transposes provisions of the World Copyright Treaty into U.S. law. Article 11 of the treaty asks the contracting parties to provide effective legal remedies to prevent the circumvention of technological measures used by authors to protect their rights. And Article 12 of the treaty asks contracting parties to make it a criminal offence if an outsider hacks electronic rights management systems, or distributes information about how to do that. ${ }^{122}$ Relying on these provisions, a Russian cryptographer was arrested for giving a presentation of how his company was able to remove security protection from Adobe e-books. And the publisher of the hacker magazine 2600 was enjoined from posting, on his website, the computer code that cracked the encryption technology used for protecting DVDs. Many who work on hacking no longer dare publish their results. ${ }^{123}$ The latest scoop of the music industry was a bill introduced by representative Berman. If this had become the law, the music industry would even have beeen allowed to hack the computers of those who are guilty of violating their copyrights. ${ }^{124}$ The music industry even prepared technical attacks at peer to peer networks. ${ }^{125}$

Egalitarian activists have not just let that happen. In response to the Berman Bill, they hit the website of the Recording Industry Association of America's website with denial of service attacks. ${ }^{126}$ They have made copyright an issue of American high politics, mobilizing resistance from legal scholars, cryptographers, technology developers, civil libertarians and, last but not least, consumer advocates ${ }^{127}$. Most importantly however, they have transposed music distribution to parts of the Internet that are almost impossible to control. ${ }^{128}$ There are many, the most popular being $\mathrm{KaZaA}^{129}$ and Gnutella. ${ }^{130}$ Another option is Internet radio going off shore. ${ }^{131}$ All in all, a serious copyright war between the music industry and hackers has been started. ${ }^{132}$

120114 F Supp 2d 896 - Napster I; 239 F3d 1004 - Napster II.

121 http://www.heise.de/newsticker/data/anw-18.08.02-002 (21.8.2002); for background see ZITTRAIN Internet Points of Control (2003) .

122 Transposed into 17 U.S.C. 1201 and 1202.

123 Yu in FindLaw's Legal Commentary (2002).

124 Proposed 17 U.S.C. 514 (a); on the background see the section by section analysis, prepared by Representative Berman, http://www.politechbot.com/docs/berman.coble.p2p.analysis.072502.html (21.8.2002); Representative Berman has withdrawn his bill in Spring 2003, http://www.heise.de/newsticker/data/anw-25.02.03002/ (1.3.2003).

This has been reported of Matt Warne, http://www.heise.de/newsticker/data/ern-18.01.03-002 (23.1.2003). http://zdnet.com.com/2100-1106-955776.html (31.8.2002).

YU in FindLaw's Legal Commentary (2002); VAN WIJK Dealing With Piracy. Intellectual Asset Management in Music and Software (2002); PESSACH Copyright Law as a Silencing Restriction on Non-Infringing Materials - Unveiling the Real Scope of Copyright's Diversity Externalities (2003) . BARTOW in Buffalo Intellectual Property Law Journal (2001). http://www.kazaa.com/us/index.htm (22.9.2003).

130 http://www.gnutellanews.com/ (31.8.2002). YU in FindLaw's Legal Commentary (2002) reports on competing file-sharing systems. 


\section{Content Regulation: The Bone of Contention with Hierarchists}

Egalitarians and hierarchists are opposed in a similarly harsh conflict. In many countries, governments try to control Internet content by their classic, hierarchic devices. A Bavarian court convicted the country manager of CompuServe for giving its customers access to pornographic parts of the Internet. ${ }^{133}$ Another German court convicted an Australian for maintaining on a website posted on an Australian server that the Holocaust had never happened. ${ }^{134}$ A local German authority has ordered all locally based Internet Service Providers to ban access to two American Nazi websites. ${ }^{135}$ A French court ordered Yahoo to make it impossible for French inhabitants to trade Nazi memorabilia on the American website of the company. ${ }^{136}$ September 11 has further spurred government attempts at getting the Internet under control, and at even transforming it into a tool for controlling the citizenry ${ }^{137}$

But again, the egalitarian opponents did not just let it happen. Their battle cry is: "The Net interprets censorship as damage and roots around it". ${ }^{138}$ Or shorter: "Keep your laws off our Net". ${ }^{139}$ They are backed by the U.S. constitution and its absolute protection of free speech. ${ }^{140}$ And they again divert traffic to peer-to-peer schemes like KaZaA and Gnutella. ${ }^{141}$ Alternatively they advise using multiple access points, like the proverbial cyber café. ${ }^{142}$

133 Amtsgericht München 8340 Ds 465, Js 172158/95, 28.5.1998, Multimedia und Recht 1998, $429=$ Neue Juristische Wochenschrift Computer Report 1998, 356; see also BENDER in International Journal of Communications Law and Policy (1998), electronically available at http://www.digital-law.net/IJCLP/1_1998/ ijclp_webdoc_14_1_1998.html (4/16/2002); GOLDSMITH in University of Chicago Law Review (1998) at note 106-111; MAYER in European Journal of International Law (2000) 151-153.

134 BGH 12.12.2000, BGHSt 46, 212 - Toeben; see also VASSILAKI in Computer \& Recht (2001); BREMER in Multimedia und Recht (2002); KOCH in Juristische Schulung (2002).

135 Bezirksregierung Düsseldorf 6.2.2002, electronically available at http:/www.odem.org/material/verfuegung/ (1.9.2002); second decision of 22.7.2002, http://www.bezreg-duesseldorf.nrw.de/cat/SilverStream/Pages/ THEMEN_Beitrag.html?query=THBTR.ID\%3d8229 (1.9.2002); on that case see also ENGEL in Multimedia und Recht (2003b). More on control via the Internet Service Providers from BIRNHACK and ELKIN-KoREN The Invisible Handshake. The Reemergence of the State in the Digital Environment (2003); ZITTRAIN Internet Points of Control (2003)

136 Tribunal de Grande Instance de Paris, ordonnance de référé, 11/20/2000, http://www.juriscom.net/txt/jurisfr/ cti/tgiparis20001120.htm (4/16/2002) ; id. Document de travail sur le rapport d'expertise, 11/6/2000, http://www.juriscom.net/txt/jurisfr/cti/tgiparis20001106-rp.htm (4/16/2002); id. Ordonnance de référé, 8/11/2000, http://www.legalis.net/cgi-iddn/french/affiche-jnet.cgi?droite=decisions/responsabilite/ord_tgiparis_110800.htm (4/16/2002) ; Ordonnance de référé, 5/22/2000, http://www.juriscom.net/txt/jurisfr/cti/ tgiparis20000522.htm\#texte (4/16/2002). See also United States District Court for the Northern District of California San Jose Division, 11/7/2001, Yahoo! Inc. v. La Ligue contre le racisme et l'antisémitisme, http://www.juriscom.net/en/txt/jurisus/ic/dccalifornia20011107.htm (4/16/2002); FOWLER, FRANKLIN and HYDE in Duke Law and Technology Review (2001); GEIST in Berkeley Technology Law Journal (2001a) at note 16 ss; GEIST in Juriscom (2001b); PENFOLD in Journal of Information, Law and Technology (2001) note 53 - note 80; BERMAN Internet and Nation State (2002) 24 s., 27 s., 64-66; REIDENBERG in Jurimetrics (2002). See also Tribunal de Grande Instance de Paris 10/30/2001, Az. 01/57676 - Front 14.

137 More from KENNEDY and SwIRE State Wiretaps and Electronic Surveillance After September 11 (2003) .

138 BOYLE in University of Cincinnati Law Review (1997) 178, citing JOHN GILMORE.

139 Ibid. in 189.

140 For a comparative analysis see KÜBLER in Sitzungsberichte der Wissenschaftlichen Gesellschaft an der Johann Wolfgang Goethe-Universität Frankfurt am Main (2000); HolZNAGEL in Archiv für Presserecht (2002); NATIONAL RESEARCH CounCIL Global Networks and Local Values (2002a) 106-132.

More from National ReSEARCH COUNCIL Pornography (2002b) 2.5 and 12.1.2.

Ibid. 2.5. 
Hierarchists retaliate in their own way. They conduct software searches through the Net for illegal contents. ${ }^{143}$ Governments are considering denial of service and virus attacks on illegal websites. ${ }^{144}$ And they aim to change the Internet architecture such that the identification of users and the establishment of virtual fences between nation-states become feasible. ${ }^{145}$

\section{The Egalitarian Infrastructure}

Many observers are convinced that the individualistic and the hierarchic attempts to impose their solidarity on the Internet are futile anyhow. ${ }^{146}$ But even if it were otherwise, it would be very unwise for individualists or hierarchists to try to do so. Economically speaking, it is not so much the out-of-pocket cost, but the opportunity cost that is at stake. If individualists or hierarchists effectively impose their will on the Internet egalitarians, they risk hampering or even destroying the infrastructure on which more and more of their own activity is built. Due to the dramatic decline in transaction costs, and distance costs in particular, a vast array of new markets has been created. Moreover, the transaction cost of policing institutions has been fallen so much that private, tailor-made institutions have become a more and more realistic option. ${ }^{147}$ Likewise, hierarchists, and governments in particular, increasingly rely on the Internet. The catchy term is e-government. Due to the Internet, government can gain much more and much better information than ever before. Along with this, in many areas regulatory cost has dropped dramatically, making central intervention more swift and powerful.

At first sight, the individualists and egalitarians might accept the argument, but declare it irrelevant on a forward looking basis. In accord with this perspective, Internet egalitarians would have done their job by creating the Internet, much as the egalitarians in East Germany ran the peaceful revolution, but virtually disappeared from the political scene afterwards. Seemingly, there is even a sound economic argument pointing in this direction. The technical core of the Internet is the TCP/IP standard. The key problem with technical standards is proliferation. Only when the standard succeeds in attracting a sufficient number of users is it to survive. The Internet, due to egalitarian efforts, has certainly been able to generate this critical mass. Once this is achieved, the argument goes, path dependence ensues. ${ }^{148}$

143 This is basically what jugendschutz.net does, a joint subsidiary of the German Länder Ministries on Youth Protection, HOLZNAGEL and KuSSEL in Multimedia und Recht (2001) 348.

144 More from REIDENBERG in Jurimetrics (2002) at note 70.

145 More from JacoBus Taming the Web. Building Fences, One by One (2001); LEMAIRE Filtering Techniques and Methods (2001)

146 Out of the rich literature see SIEBER in Computer \& Recht (1997); WEINBERG in Hastings Communications and Entertainment Law Journal (1997); KÖHNTOPP, KÖHNTOPP and SEEGER in Kommunikation und Recht (1998); REIDENBERG in Texas Law Review (1998) 557-560; SIEBER Verantwortlichkeit (1999) 43-96; Fox in Roßnagel (2001); LEMAIRE Filtering Techniques and Methods (2001); NATIONAL RESEARCH COUNCIL Pornography (2002b) in particular 2.5 and 12 .

147 See above 1 a.

148 From the rich literature see only DAVID in van Ark (1997); DAVID in Engel and Keller (2000) ; more at http://pages.stern.nyu.edu/networks/biblio_hframe.html (1.9.2002). 
Yet this misinterprets the success of the Internet. It contains as much of a social infrastructure as a technical one. The very fact that the Internet has become so extremely popular generates a need to permanently readapt it to a changed environment. The Internet is a living entity. What makes it an infrastructure for competing ways of life is not so much a historic achievement, as its high evolutionary potential. This is not to say that the individualists or the hierarchists should give up their core concerns. On the contrary. Isolated egalitarianism is no better than isolated individualism or isolated hierarchy. But the competing ways of life should carefully avoid damaging the egalitarian infrastructure of the Internet. In other words, they should seeks more intelligent ways of governing the egalitarians from without. ${ }^{149}$

\section{Deterministic vs. Probabilistic Governance}

\section{A Decomposed Analytic Approach}

This paper is inspired by cultural theory. But it deviates from cultural theory in that it does not conceive of the balancing of competing ways of life exclusively as a natural phenomenon. It does not deny the possibility of unplanned, eruptive re-balancing. But it believes that the competing ways of life can actively seek and even impose balancing. It thus treats balancing as a governance task. Put differently, it translates insights from cultural theory into governance challenges. This invites a decomposed approach. The egalitarian challenge partly presents itself to governance attempts in more familiar ways. Put differently, the egalitarian challenge can be reinterpreted in ways that lend themselves to better understood governance responses. None of these re-interpretations will be able to capture egalitarianism entirely. Attempts to confront the balancing challenge directly are therefore valuable. But in terms of practical politics, it makes sense to consider more modest approaches beforehand. It does not seem unlikely that these better explored responses might have the potential to create a somewhat tilted, but still acceptable, balance between the ways of life.

Specifically, incentive regulation of egalitarians (section 2) is as troublesome as regulation by order (section 3). What remains is at most probabilistic (section 4).

\section{Trouble with Incentive Regulation}

If individualists have it their way, governance will rely on incentives. This is no irresponsive attitude. Individualists can handle regulatory incentives better than other acts of intervention.

149 The point apparently has not been made in literature. But see KoLLOCK and SMITH in Herring (1996) at note 9: managing the virtual commons presupposes respecting the ability of community members to devise their own rules; LESSIG and RESNICK in Michigan Law Review (1999) 423: "We might make the Net safe for kids, but in consequence make it a fundamentally regulable space”; NACHBAR in Minnesota Law Review (2000) 247-259: regulators should care about how users "perceive" the Internet, once it is regulated differently. 
Centrally imposed restrictions do hit them where they are most vulnerable. If the target is known to be individualistic, a regulator is thus well-advised to pursue its goals by changing incentives.

But egalitarians are different. They do not perceive of themselves as lonely wolves, striving for utility maximization. Their behaviour is likely to be driven by group demands. They may not even perceive the changed restrictions, since their view of the world does not motivate them to seek such changes. They may react in unexpected, seemingly irrational ways, since they feel their value systems hurt by the "commercialisation" inherent in incentive regulation. And successful incentive regulation may destabilize the egalitarian Internet movement internally, thus hampering the social basis of the Internet as an infrastructure.

\section{Trouble with Order}

Likewise, the hierarchists are likely to run into trouble if they get it their way. Pure hierarchic governance is by order. Again, this is appropriate if the regulator knows his targets to hold hierarchic beliefs. If they do, they believe in experts, rationality and predictability. If government appeals to expert knowledge and to procedures seen as truly getting the best input, it is likely to hit these targets where they are most responsive. In accord with the hierarchical perspective, validity, formality, sovereignty and force are thus coupled with expertise, specialization, rationality and procedure.

But egalitarians are not likely to be very responsive to any of them. They define themselves as members of their smaller, egalitarian communities, and at best on a secondary level as members of the larger, intervening society. Their internal discourse is not likely to be couched in the terms used by rationalist experts. They are therefore likely to misinterpret the resulting order, or to overlook it entirely. Since they do not believe in technocratic expertise, they are even likely to openly resist such governance attempts. Due to its monopoly of physical force, and to the many other resources at its disposal, government may nonetheless be able to break the egalitarian will. But if it does, it also damages the social basis of the egalitarian infrastructure of the Internet.

\section{Probabilistic Governance}

A first way of saying what both effective and wise governance of egalitarian targets might look like is: it must shift from deterministic to probabilistic governance. ${ }^{150}$ The term means: The

150 The distinction between deterministic and probabilistic approaches is culled from psychology. There it is used to characterise different approaches to human behaviour. Deterministic approaches posit the ability to predict, maybe even influence behaviour in a fully analysable way. Probabilistic approaches object that man is not made for a predetermined, but for a fundamentally uncertain environment. Accordingly, his behavioural programs are understood to be highly adaptive, and hence not fully predictable. The behavioural programs make some type of behaviour more probable, without determining it altogether. See e.g. GIGERENZER, HOFFRAGE and KLEINBÖLTING in Psychological Review (1991). 
regulator cannot be, and should not purport to be, certain about the effect of its intervention. It should be content with making the desired outcome significantly more likely.

Given the repeatedly mentioned characteristics of egalitarianism, this statement is bound to be true. But it remains conspicuously unspecific. At closer sight, almost all governance is probabilistic, not deterministic. Order usually has an implementation deficit. ${ }^{151}$ Regulation by incentive does not even want to change the behaviour of all its addressees. Those with an asymmetrically high adaptation cost are expected to stick to their earlier behaviour. ${ }^{152}$ Moreover, it is next to impossible for government to correctly predict how an industry adapts to a change in restrictions. The more the governmental estimation is off the mark, the more the intervention is only probabilistic. Evolutionary economists stress that addressees are by no means forced to merely adapt to regulatory intervention. They can rather take the impulse as a trigger for creativity, producing an unpredicted reaction. ${ }^{153}$ Since government cannot know this reaction in advance, each act of intervention is probabilistic. Systems theory stresses the self-contained character of social subsystems, like the economy. This autopoiesis endows the subsystem with the ability to ignore regulatory intervention altogether. Even if it is responsive, the intervention is not taken at face value. Instead it is made part of internal communication, and is bound to be altered that way. ${ }^{154}$ Again, this implies that any governance attempt is at best probabilistic. ${ }^{155}$ The following is therefore an attempt to be more specific, and to say why attempts to govern egalitarians from without must indeed be probabilistic.

\section{The Social Embeddedness Challenge}

Outside of social scientists quarters, modelling is not seen as a matter of course. Those who define themselves as actors, rather than observers, frequently complain about the counterfactual assumptions on which models are built. Yet, on epistemological grounds, it is not difficult to defend modelling. Those who want to see everything will see nothing. ${ }^{156}$ It is not important whether the assumptions underlying a model are factually correct. What counts is the analytic or predictive power of the model. The best way of putting the implication for research practice comes in a distinction common in psychology. Models can and should ignore unsystematic error.

151 See again WINTER Vollzugsdefizit (1975); MAYNTZ Implementation (1980) and LÜBBE-WoLFF Umweltordnungsrecht (1996)

152 Economists do even stress that this ability to react to differences in adaptation costs is the key comparative advantage of the tool, for a basic treatment see PIGOU The Economics of Welfare (1932)

154 Basic LuHMAnN Ökologische Kommunikation (1986) 44 f. and passim.

155 Actually, systems theorists are divided over the question whether any governance is illusionary, as the founding father of systems theory has it, LUHMANN in Zeitschrift für Rechtssoziologie (1995) 4, or whether it is demanding, but feasible, as TEUBNER Recht als autopoietisches System (1989) 83-85 has it, see also TEUBNER in Archiv für Rechts- und Sozialphilosophie (1982). 
But they should respond to systematic bias. ${ }^{157}$ Assumptions may thus be wrong, but they should not be misleading.

With respect to egalitarians, one of the basic assumptions of rational choice analysis is problematic. Understanding their behaviour, and hence governing them, presupposes taking social embeddedness seriously (section 1 below). It also encompasses the secondary risk of group reactions (section 2). Outsiders can respond to this challenge by having governance at two separate levels (section 3). Alternatively, they can also try to exploit the feature of social embeddedness for their own purposes (section 4). Or they can change the addressee and target a collective egalitarian actor, rather than the individual members of an organisation or collective (section 5).

\section{Social Embeddedness as a Restriction to Governance}

The traditional intellectual tool for understanding individualists is the rational choice model prevalent in economics. Analysis starts with the individual. The individual is endowed with a well defined set of preferences. He or she optimises his or her behaviour in the light of changing restrictions. Law and economics, and institutional economics more generally, use the same methodology to understand hierarchic intervention, and it has been marked by considerable success. ${ }^{158}$ Applying the same methodology to egalitarian behaviour is much less promising, however. Cultural theory demonstrates why. In ideal types, egalitarianism is characterized by a low degree of grid involvement, and a high degree of group involvement. ${ }^{159}$ To understand egalitarians, is it crucial to understand the group dimension. ${ }^{160}$ If governing the egalitarians is the regulatory task, the social embeddedness of individual behaviour must not be overlooked. ${ }^{161}$ When deciding how to react to regulatory demands, members of egalitarian movements are likely to be driven by the expectations of the group. Government may be able to override this embeddedness. But it should at least be aware that social embeddedness is a serious impediment to governance effects.

157 Basic KaHNEMAN, SLOVIC and TVERSKY Judgement under Uncertainty (1982)

158 Programmatic BECKER Human Behavior (1976) ; for an introduction to institutional economics see FURUBOTN and RICHTER Institutions (1997)

159 See above I 2 and I 3.

160 Consequently, the argument also points to a problematic limitation inherent in the rational choice analysis of hierarchists, and of hierarchic intervention. For cultural theory characterises the hierarchic way of life by high grid and high group. The latter component is not captured by rational choice models. This explains, for instance, why rational choice models of law systematically overlook normativity, personality or identity. For a theoretical treatment see JAKOBS Norm, Person, Gesellschaft (1999). See also ENGEL in Rengeling (2001a) on the limitations inherent in rational choice analyses of law as a governance tool.

161 See GrANOVETTER in American Journal of Sociology (1985), criticising rational choice in general, not only with respect to egalitarian targets, however. 


\section{The Risk of Group Reactions}

The social embeddedness barrier is not even purely mental. It is thus not confined to behaviour that a member of an egalitarian movement deems unthinkable. Even if outside actors succeed in breaking the will of individual egalitarians, they cannot be sure to reach their regulatory aims. For egalitarian movements supervise their members. They govern them via social norms. If one member violates a group norm, it is sanctioned by its peers. This can be done via the already mentioned mechanisms of shaming and expulsion. Typically, the individual members will anticipate these sanctions and not even dare to deviate from group expectations. Conversely, members may count on group support if outside actors pick those targets they expect to be weakest. Stronger members will rally to their support. Individuals will not be isolated when they combat governance. They are not confined to their individual inventiveness, when they seek for creative ways around the law.

\section{Two Level Governance}

One way for outside actors to parry the social embeddedness challenge is two level governance. On one level, it tries to make the egalitarians more regulable. ${ }^{162}$ On another level it exploits the new regulatory opportunity. Usually, both steps will be sequential. But sometimes, both steps may be taken almost simultaneously. Specifically, at the first level, the outside actor reduces the degree of social embeddedness. At the second level, it targets the more disembedded individuals.

The well-known distinction by Albert Hirschman demonstrates how this can be done. Outside actors can offer the members of egalitarian movements new options for exit or voice. ${ }^{163}$ Exit means that members are siphoned away from the egalitarian movement or, in a dynamic perspective, new individuals are prevented from becoming members. Voice means, that internal opponents are strengthened to the detriment of the dominant ideas and members. Both mechanisms do thus rely on differences between individual members of an egalitarian movement. Such differences are indeed likely. They can be cognitive or motivational. In the cognitive case, the individual members do not disagree about goals. But they have different convictions about what reality is like, and how social betterment could be brought about. In the motivational case, the members differ in egalitarian zeal. Some hardliners do exclusively see the world through egalitarian lenses. Followers may have some sympathy with the egalitarian cause. But they weigh it against individual benefit, or against expert recommendations. If the egalitarian actor exhibits fundamentalist traits, members may even be cast under its spell against their will. ${ }^{164}$

162 The graphic term has been coined by LESSIG and RESNICK in Michigan Law Review (1999) 423.

163 See again HiRsCHMAN Exit voice (1970)

164 For an elucidating account of individuals under a fundamentalist spell see KuRAN in Public Choice (1989); ARCE and SANDLER in Journal of Institutional and Theoretical Economics (2003). 
Voice takes place at the interior of an egalitarian movement. As long as outside actors do not target the egalitarian movement as such, they can therefore not influence voice directly. But they can do so indirectly. For credible exit options give members a choice. Rather than leaving the movement altogether, they can use the exit option as a threat point in internal conflict. If outside actors want members to leave the egalitarian movement, they can choose between positive and negative sanctions. Positive sanctioning means offering those who actually leave a premium. Negative sanctions do threaten those who stay or enter.

Depending on circumstances, more indirect approaches may suffice. Internally, egalitarian movements organise themselves like commons ${ }^{165}$. In that event, the group internally faces a serious incentive problem. Each member has an incentive to free ride on the efforts of its peers ${ }^{166}$. Luckily, there is enough evidence for groups overcoming the social dilemma. ${ }^{167}$ But the conditions for success are rather demanding. A key element is the group being sheltered from the outside intervention into internal governance. ${ }^{168}$ Therefore it is not very difficult for outside actors to destabilize an egalitarian regime. There is also a more constructivist explanation for this. In order to have members contribute to the common cause, the egalitarian movement must provide its members with an agreed upon definition of the social problem. Not so rarely, outside actors are able to shake this belief. This may trigger a process of unravelling.

\section{Exploiting Social Embeddedness for Governance Purposes}

Outside actors do also have the opposite strategy at their disposal. Rather than reducing the degree of social embeddedness, they can exploit this behavioural trait for their own purposes. That way, social embeddedness is no longer perceived to be a challenge, but is viewed rather as an opportunity for governance. Much like individualists governed by incentives, or hierarchists governed by technocratic expertise, egalitarians are hit where they are particularly responsive. If outside actors succeed in this, their governance attempts should be even more powerful than standard governance tools could ever have hit standard addressees. Governance becomes tailor made. It exploits the knowledge about the way of life predominant among addressees. Put differently, cultural theory calls for a more sophisticated concept of good regulatory targets. In its view, this is not a generic concept. Rather each way of life is particularly responsive to a specific set of regulatory interventions.

The good news for regulators is that members of egalitarian collectives are trained to respond to normative expectations. If outside actors succeed in entering the internal logic of an egalitarian movement, an implementation deficit is much less likely than vis-à-vis predominantly individu-

KOLLOCK and SMITH in Herring (1996) at note 1.

166 Classic HARDIN in Science (1968); for a modern analysis see CORNES and SANDLER Externalities (1996)

167 See again Ostrom Governing the Commons (1990)

168 Ibid. 101. 
alistic or hierarchic actors. Again, this can also be done indirectly, triggering internal regulatory dynamics within the egalitarian movement.

\section{Collective Actors as Regulatory Targets}

Outside actors are not bound to take the social embeddedness of members of egalitarian movements into account. Instead they can shift the addressee of their governance attempt altogether and address the movement itself (section a below). Due to the characteristically low degree of corporatisation, however, this is not easy to do (section b). This is why outside actors might want to switch to two level governance and impose a higher degree of corporatisation beforehand (section c).

\section{a) Shifting the Addressee}

The members of egalitarian movements are strongly embedded in the belief system and in the social norm of their group. Addressing them individually requires overcoming this embeddedness, and precluding their peers from intervening. Against this backdrop, it would be attractive to swap the addressee. It may be both more effective and easier to directly address the egalitarian movement. If the egalitarian actor itself were committed, this would also help overcome the unpredictability of internal dynamics. And the actor would be expected to effectively police the commitment internally.

Governing egalitarian movements with egalitarian instruments should be easiest. Thus the approaches studied in later sections should be applicable: cognitive governance, belief changing, contextual governance and imposed balancing. ${ }^{169}$ But even applying the individualistic or hierarchic approaches might be easier in relation to the egalitarian movement as such.

Governance by incentive presupposes that the egalitarian movement behaves differently in its external relations than in its internal ones. The movement must be willing and able to distinguish a logic of influence from a logic of membership. ${ }^{170}$ Not all egalitarian movements are. The more they are entrenched in an ideology, the less they might be able to internally explain why they violate externally what they cherish internally. But not all egalitarian movements are like that. It also is not necessary that they behave exactly like an ideal type individualist or hierarchist. It is enough if they are sufficiently responsive to incentives or orders.

It is not unlikely that egalitarian movements will be willing to react to incentives. For egalitarian movements need a lot of resources if they want to live their way of life internally: money, information and access to the ordinary political system are among them. Outside actors can lure egali-

169 See below V 3, VI 3, VII 3 a, VIII 4.

170 The distinction has been coined by SchMiTTER and STREECK Business Interests (1999) . In its context of origin, the distinction was applied to organisations that define themselves by their impact on the outside environment. But it carries over to the entities under scrutiny here. 
tarian movements into negotiations by offering some of these resources. Or they can threaten to make access to such resources more burdensome. ${ }^{171}$ If government intervenes, it cannot only order the egalitarian movement how it ought to behave. It also can use its sovereign powers as bargaining chips. This is what frequently happens under the heading of regulated self-regulation, or bargaining in the shadow of hierarchy. ${ }^{172}$ A particularly promising negotiation object concerns the institutional framework for defining the borders of a group. Egalitarian movements tend to have a strong interest in a clear boundary between insiders and outsiders. They will at least want autonomy to decide who becomes a member and who not. They will also be interested in eschewing outside interventions into exit or voice options. If they are missionary, they might also want extra opportunities to attract new members.

\section{b) Degree of Corporatisation}

Addressing an aggregate actor ${ }^{173}$ presupposes a defined collective entity. This is not difficult if the actor has legal personality, a discernible organisation, cognisable members, and its own resources. But a typical egalitarian movement has none of these. Political scientists speak about a collective, rather than a corporate actor. ${ }^{174}$ In the pure case, egalitarian movements are permanently fluid. There is no internal role differentiation. No spokesman is able to commit the actor externally. Even the borderline between the interior and the exterior is soft. Members are tied together by nothing other than communication. ${ }^{175}$ Governing such an actor is indeed like nailing a pudding.

But not all egalitarian movements are this extreme. Neither to they all follow the definition of a pure corporate actor. Rather, they exhibit some features of corporatisation, like role differentiation, internal organisation, external representation, independent resources. Collective and corporate actors are thus not categorically different. They are rather on a continuum, stretching from the ideal collective to the ideal corporate actor. ${ }^{176}$

\section{c) Two Level Governance}

With this insight in mind, another option for two level governance comes into purview. Outside actors can make egalitarian movements more responsive to governance attempts by first imposing a higher degree of corporatisation on them. Another way of making the point: they can be induced to organise or to institutionalise. This can be brought about by the very approaches listed

171 I have further developed the idea with respect to fundamentalists, ENGEL in Journal of Institutional and Theoretical Economics (2003c).

172 The latter term has been coined by SCHARPF Games (1997) 197; for a rational choice treatment of the actual negotiations see ENGEL in Staatswissenschaften und Staatspraxis (1998).

173 This generic term is used to denote both collective and corporate actors, see directly below.

174 SCHARPF Games (1997) 54-58.

175 See ThOMPSON, ELLIS and WILDAVSKy Cultural Theory (1990) 6; HolTGREWE in Allmendinger (2001) 412.

176 German lawyers will not find this surprising. They are accustomed, in their corporate law, to treat hybrids between collective and corporate actors called "Gesamthand", typical for business partnerships. See SCHMIDT Gesellschaftsrecht (2002) § 8 III and IV. 
in the section in which direct addressing of collective actors was discussed. It can be done the egalitarian way. But outside actors might also use incentives or order for the purpose.

\section{The Cognitive Challenge}

\section{The Twofold Constructivist Challenge}

Cultural theory is a constructivist approach. It rightly posits that not only egalitarians construe the world. Individualists, hierarchists and fatalists all do. But those who construe the world typically take the outcome of this social exercise for granted. The typical individualist believes he just behaves rationally if he maximizes his utility. A typical hierarchist thinks he asks rationally if he asks for scientific advice. And the typical egalitarian finds it irrational not to mobilize all individuals for the common cause. ${ }^{177}$ Any governance attempt across ways of life is therefore faced with a constructivist challenge.

But in the realm of governance theory, individualists and hierarchists have a long-standing relationship. Due to transaction cost involved, before the advent of the Internet private institutions were a rare exception. In order to lay the institutional foundations for markets, individualists thus always needed governmental input. Conversely, no government can do without money. Governments all over the world therefore routinely care for the economy, and thus for individualists. Cultural theory rightly objects that the social foundations of both markets and government are of no less importance. If government cannot rely on something like generalized trust in the population, its power quickly erodes. And markets quickly lose their coordinative power if social discourse no longer defines what is a good and a bad, ${ }^{178}$ or what is an industry for that matter. ${ }^{179}$

But in practical terms, the constructivist challenge for governing egalitarians is much greater. There are no trodden paths for making sense across different ways of life. The egalitarian logic is little understood by those who manage individualist or hierarchic governance. Therefore it is necessary to make the challenge explicit. It has a cognitive and a motivational aspect. The cognitive aspect is addressed in this section (section 2); section VI looks at the motivational aspect, i.e. the belief challenge. Cognitive Governance is a demanding exercise (section 3). It can consist of exploiting knowledge about foreign cognition (section 4), or of changing foreign cognition (section 5). they find it irrational to strive for anything, since the environment is not predictable, and even less open to deliberate change.

179 WHITE Identity and Control (1992) 


\section{The Cognitive Part of the Challenge}

Copyright in digitally recorded music is a good example of the cognitive challenge. If somebody buys a CD, compresses it in MP3 formate, stores it on his hard disc and sends it to his six best friends as an e-mail attachment, for the music industry this is theft. Quite a number of artists see this differently. Some of them simply regard being heard as more important than making some extra money. Others do not forget that they make music for a living. But they see the different distribution channels holistically. If they do not make money from these six friends listening to their music, they at least gain in popularity. Some of these friends might like their music so much that they later buy a CD or go to a live performance. Specifically, they see this as a distribution issue. The large majority of mildly popular musicians do not gain much from record sales or royalties anyhow. For them, a full concert hall is much more important economically. Those who stand to lose because of music file sharing are those who are in the charts. ${ }^{180}$

If outside actors want to have an impact on egalitarian behaviour, they are well-advised to understand how the egalitarians define the social problem. Admittedly, the above example is an extreme case. The egalitarians define as a public good what the individualists define as a public bad. But even if the difference is less pronounced, its repercussions on governance attempts can be profound. If the egalitarians are indifferent to what individualists or hierarchists see as a serious social problem, it will not be feasible to enter the egalitarian logic. The theoretically most powerful governance tool is thus not available. In principle, governance by incentive or order remains possible, but there are likely to be considerable implementation problems. The outside actor will need a lot of monitoring and enforcement effort to impose its will on the egalitarians.

If government orders the members of egalitarian groups to fulfil a precisely defined action, the cognitive problem is smaller. Even if they do not share the definition of the social problem lying behind the order, they still might get the concrete message. But the cognitive problem looms large, once the outside actor is either unable or unwilling to be that precise. Designing rules with high precision is often just too costly. Even if the out of pocket regulatory cost seems affordable, the opportunity cost often is not. For precise rules give little room for evolution. This is not good once the individualists and the hierarchists recognize that they need the egalitarians to run the Internet infrastructure.

\section{Cognitive Governance}

The logical reaction to the cognitive challenge is a cognitive component of governance. In the borderline case, the problem is purely cognitive. Addressees are willing to exhibit the behavioural change. There is no motivational resistance. They simply are caught in a construction of reality that makes it impossible for them to understand the demand. Real life cases will seldom

180 More from IAN Internet Debacle (2002b); IAN Fallout (2002a) ; see also KU in University of Chicago Law Review (2002). 
be that pure. But governance across ways of life will also rarely be purely motivational. Precisely because ways of life construe the world differently, outside actors are well-advised to add a cognitive component to their governance attempts. The following outlines how this might be done.

\section{Exploiting Knowledge about Foreign Cognition}

Cognitive governance does not necessarily imply that the outside actor has an impact on how his addressees see the world. It can be enough for him to understand their construction, and to adapt his intervention to it. Sometimes just a bit of rhetoric will do. In the case of the egalitarians, this might mean telling them why it is appropriate to change behaviour. ${ }^{181}$ In other cases, a shift to a different regulatory tool may help. This may, for instance, make it advisable to use command and control regulation rather than incentives. For the statute itself can give reasons. More importantly even, when applying the statute, the administration has an opportunity to argue with the addressees. ${ }^{182}$ It finally may be advisable to stick to the ultimate regulatory goal, but to operationalise it differently. ${ }^{183}$ To go back to the example of the music industry: individualists still might want the opportunity to make money from selling music. But they might be willing to consider business models that do not make it necessary to chase each and every unauthorized transmission of digital music clips. ${ }^{184}$

\section{Changing Foreign Cognition}

\section{a) Introduction}

Such unilateral adaptation to egalitarian constructions will not always suffice. If not, the outside actor must attempt to change the way the egalitarian addressee constructs the world. This may mean establishing an agreed upon definition of the social problem. But it may be enough for the outside actor to induce a change in the egalitarian construction that makes it sufficiently responsive to governance. In that case, the two different definitions of the social problem coexist. But they become complementary in a way. Not so rarely this will imply that the outside actor itself also partly or fully changes its definition of the social problem. As with the social embeddedness challenge, outside actors can design cognitive governance as a two level exercise, with the cognitive component coming first. But this need not be so. Depending on the case, it can be as effective to carry out the cognitive and the motivational action simultaneously.

181 On the importance of a logic of appropriateness for egalitarians see below VI 1.

182 More on the cognitive component inherent in command and control regulation from ENGEL in Rengeling (2001a)

183 On operationalisation more in ENGEL Abfallrecht (2002a) 100-110.

184 Such business models are presented by IAN Internet Debacle (2002b); IAN Fallout (2002a) 
Sometimes, just getting the facts right will do (section b below). Things are more complicated if the competing definitions of the social problem partly rely on implicit knowledge (section c). The outside actor also needs a different approach if it perceives its addressees to be biased (section d). In all the instances mentioned thus far, the governance impediment is purely cognitive. In practice, cognition and motivation often go hand in hand. In that case, arguing might be a better strategy for overcoming the cognitive problem (section e). Finally, the outside actor may use a more indirect route and create surprises for the egalitarians, reckoning that they will feel urged to change cognition from within (section f).

\section{b) Information}

Cognition consists of more than processing information. The environment permanently offers much more information than the human mind can handle. ${ }^{185}$ Organisation and technology can overstep the limitations of the individual mind. But this creates new problems. And even their capacity to assimilate information is strictly limited. Cognition is therefore above all a selection exercise. This explains why the mere transmission of information from outside actors to egalitarians can make a difference. Thereby, egalitarians are called upon to take information into account that they had overlooked before.

Those who are first exposed to constructivist thinking tend to react with questions like: Do you claim that water flows upwards? ${ }^{186}$ Facts seem so clearly beyond doubt that constructivism is equated with academic nonsense. But not all the reality surrounding us is as simple as gravity pulling water downwards. The more the world progresses, the more of our environment consists of human behaviour anyhow, and not of nature untouched. Making sense of such an environment presupposes seeing much more extended chains of influence. To use an example that has made it into the headlines: Is there climate change at all? If so, is it man-made, or is it just another of the earth's autonomous changes? If it is man-made, which input has how much of a detrimental effect? In such cases, complex causal or functional chains of influence must be pinned down. This is per force an interpretative exercise. The determination of the facts is itself value laden. The chains of influence between the Internet as a technology and its impact on social relations are at least as complex. Establishing a factual basis on these issues is therefore inevitably a social exercise. Transmitting information across ways of life in such instances means transmitting different interpretations of a fairly complex reality. If they engage in this, outside actors offer different interpretations to the egalitarians, aiming at bringing a change in the egalitarian interpretation of the facts about.

Implicitly, that way the outside actors also transmit another type of information. They inform the egalitarians about how individualists or hierarchists interpret the facts, and thus define the social problem. Of course, they can also transmit that information explicitly. Giving the egalitarians 
that information can make sense. For not so rarely, the different ways of life disagree about the reasons, but agree about the outcomes. If both sides know that the conflict is thus limited, they may be willing to give up resistance to agreed upon solutions. ${ }^{187}$

\section{c) Transmitting Implicit Knowledge}

Not all information is as easily transmissible as assumed in the above section. If it is not, it is commonly called implicit knowledge. Within a social setting everybody knows. But this knowledge is transmitted by enculturation or professional training. To get access to such knowledge, one must in principle become a member of the group. ${ }^{188}$

The idea of implicit knowledge marries well with the idea of competing solidarities. For a way of life is characterized by what is taken for granted by its partisans. Among themselves, there is little need to make the underlying assumptions explicit. To do so may even seem unwise, since what is taken for granted is not argued at all. Governance across ways of life, however, may make it attractive to engage in the explication of the implicit knowledge. For it may be possible to win over the egalitarians merely by telling them which elements of reality they neglect. Such an explication of implicit knowledge is not always feasible. But as the grammar of languages can be fleshed out, these underlying assumptions can frequently be couched in clear language. ${ }^{189}$

\section{d) Debiasing}

In behavioural economics, and in the related field of behavioural law and economics, biases are centre stage. As already mentioned, this approach, while giving up some of the underlying assumptions, is still close to the rational choice model. ${ }^{190}$ Critics rightly point out that the rational choice model is not a good normative benchmark in highly uncertain and quickly changing environments. ${ }^{191}$ But when employed in a more generic way, the possibility of cognitive mistakes cannot be denied altogether. On the contrary, cultural theory adds to the list of plausible reasons. Since individuals strongly embedded in just one way of life tend to adopt an eschewed view of reality, they are prone to commit cognitive errors. Debiasing is thus a promising strategy for outside actors. ${ }^{192}$ The parallel to the psychological discussion should, however, also serve as a warning. Mere enlightenment hardly ever suffices to overcome a bias. And quite some biases

187 This opens up an opportunity for an “incompletely theorized argument”,SUNSTEIN in Harvard Law Review (1995); see also ENGEL in Rechtstheorie (2001b).

188 More from COWAN, DAVID and FORAY in Industrial and Corporate Change (2000).

189 See again Ibid. in .

190 See again KAHNEMAN, SLOVIC and TVERSKY Judgement under Uncertainty (1982)

191 This is the basic tenet of GIGERENZER, TODD and ABC RESEARCH GROUP Simple Heuristics (1999) ; see also GIGERENZER in Gigerenzer (2000)

192 On debiasing as an approach from behavioural law and economics see e.g. KELMAN, RoTTENSTREICH and TVERSKY in Sunstein (2000) $73 \mathrm{f}$. and passim. 
do even resist outright training. ${ }^{193}$ It is not unlikely that systematic cognitive errors originating in the embeddedness in the various ways of life are also hard to correct.

\section{e) Arguing}

Only in theory can cognition and motivation be separated clearly. In practice they are closely intertwined. ${ }^{194}$ Even if the outside actor perceives the impediment to governance success as being cognitive, the remedy might need a motivational flavour. One tool that oscillates between cognition and motivation is arguing. ${ }^{195}$ If argument is employed, the alternative interpretation of the situation is not imposed on the egalitarian addressees. Nor is information merely exchanged. Rather, the outside actor purports to engage in serious discourse with the egalitarians. In this discourse, not only competing stories are at stake, so are the underlying normative convictions along with them. Both sides engage in deliberation. They jointly search for the most appropriate definition of the problem, and for the swiftest reaction to it.

To be effective, arguing requires a certain willingness on the side of the addressees to engage in a serious dialogue. The more an egalitarian actor is ideological or even fundamentalist, the less it will be willing to expose itself to such a risk. But even in such a hostile environment, arguing is not hopeless. If the egalitarian movement is composed of members of different zeal, the outside actor can start discourse with the internal opposition. This might then translate into voice internally, and trigger an internal erosion of convictions over time. Alternatively, if the movement as such cannot avoid some outside contact, the outsiders can hit on a strategy of argumentative selfentanglement. Once the egalitarian actor has committed to some buzz words or principles, the outside actor can use this as a handle for deeper inroads later on. ${ }^{196}$

193 A well-known example is the so-called hindsight bias, i.e. the inability to make a neutral ex ante assessment of risk, once it is known to have materialised, more from RACHLINSKI in Sunstein (2000)

194 Striking proof for this is the reduction of cognitive dissonance. If they realise that they must live up to an outcome contrary to their original preferences, people often change their preference in the interest of preserving self-esteem, see FESTINGER Cognitive Dissonance (1957)

195 Arguing has become fashionable among social scientists. For an overview of the rich literature see RISSE in International Organization (2000).

196 Such a simultaneous argumentative attack from within and without has been successful in improving the human rights situation in countries like the Philippines, Kenya or Morocco, RISSE, JeTSCHKE and SCHMITZ Menschenrechte (2002) ; see also RISSE in Politics \& Society (1999).

Another successful example of imposed discourse is child labour. The International Labour Organisation failed to improve the situation in developing countries while presenting the issue as one of human rights. The developing countries objected that the state of their national economies did not allow for such humanitarian luxury. The situation improved, however, when the ILO changed the discourse. It stressed that the developing countries destroy their own economic evolution if they do not allow the next generation to build human capital early in life. THOMAS RISSE pointed me to this case. The actual case study is currently being undertaken by CORNELIA UlBeRT, Free University of Berlin. Specifically, she is looking into the negotiations on the ILO Convention on Eliminating the Worst Forms of Child Labour, C 182. 


\section{f) Creating Surprises}

One final cognitive strategy is indirect. The outside actor does not try to have a direct impact on the cognition of the egalitarian movement and its members. It rather strives to bring them into situations that make them change their mental models themselves. In other words, it artificially creates surprises for them.

The idea of governance by surprise does have a background in cultural theory. One of the central tenets of this approach is a theory of surprises. ${ }^{197}$ But cultural theory, as it stands, is not about governance. In accord with its perspective, surprise is not artificial, but natural. It happens when a way of life bumps into reality unexpectedly. ${ }^{198}$ Moreover, in the conceptual framework of cultural theory, surprise does not alter ways of life, but dislodges individuals so that they fall into one of the competing ways of life. ${ }^{199}$ All this seems understandable, but too narrow. There is no need to think that the construction of reality within the various ways of life never changes. And it also seems both feasible and appropriate to make the idea of surprises normative. ${ }^{200}$

Practically speaking, creating a surprise means deliberately bringing an egalitarian movement, or some of its members, into a learning situation. Reality presents itself to them in such an unexpected way that they feel urged to search for alternative interpretations, deviating from their former mental models. ${ }^{201}$

\section{The Belief Challenge}

When analysing the cognitive challenge, the close link between cognition and motivation has already been highlighted. This section looks at beliefs, i.e. the motivational side of social construction. It presents the resulting challenge for governance (section 1 below). It then explores two alternative reactions: exploiting foreign beliefs (section 2), or changing them (section 3).

\section{The Challenge}

There are many competing terminologies that can be used to express the issue. At closer sight they obviously are not identical. But for the purposes of this endeavour, it is sufficient to present them in order.

197 ThOMPSON, ELLIS and WiLDAVSKY Cultural Theory (1990) 69-75 and passim.

198 Ibid. Cultural Theory $69 \mathrm{f}$.

199 Ibid. Cultural Theory 3.

200 If partisans of cultural theory are not willing to buy that addition to their theory, they might be reconciled by a distinction between the way of life as a communicative construct, and actors predominantly adhering to one of these ways of life. In that conceptualisation, surprise would only have an impact on the latter.

201 This interpretation brings the approach close to what has been called fundamental learning. It happens in situations of high perceived uncertainty, see SIEGENTHALER Regelvertrauen (1993) 
One distinction opposes interests and ideas. ${ }^{202}$ The basic message is directed against rational choice analysis. Man is not only motivated by interest. He also cares about ideas. ${ }^{203}$

A second distinction opposes a logic of consequentialism to a logic of appropriateness. ${ }^{204}$ People are not always cold blooded maximizers of some individual utility. They care about what their peers see as appropriate behaviour. An old fashioned way of making the point is: morals matter. ${ }^{205}$

A third conception moves away from the idea that individuals behave like monads. It stresses that individuals do not only seek profit, or utility more generally, but that they need a socially defined identity. ${ }^{206}$ The psychological underpinnings of this idea date as far back as Adam Smith. For him, the central driving force for human behaviour is a search for "self-approbation". It can originate in the explicit approbation by others. But outsiders can only observe action, not intention. Therefore the ultimate judge is the self, asking itself whether the intention was morally acceptable. ${ }^{207}$ Modern language for a closely related idea is motivation by self-esteem. ${ }^{208}$

One final way of making the point is that people care about fairness, even if that means that they must forego opportunities for gain, or put up with some loss. ${ }^{209}$ One's social construction fairly strongly influences which outcome is considered. ${ }^{210}$ A closely related concept says people care about socially constructed entitlements. ${ }^{211}$

Depending on its scope, the logic of appropriateness can weaken the logic of consequentialism, it can override it, or it can even create a motive for actively combating the outside actor. Psychology calls the latter reactance. ${ }^{212}$ While, at least in principle, the cognitive challenge turned out to be the same for all ways of life, the belief challenge is not. There is a significant difference in degree, depending on the way of life addressed from the outside. This is due to the fact that the four basic solidarities exhibit different combinations of grid and group. The belief challenge in egalitarianism is high, since this way of life is characterized by a high position on the group scale. Arguably, the belief challenge for addressing egalitarians is even higher than for addressing hierarchists. For hierarchists also rank high on the group scale. But along with this, their position on the grid scale is also high. Therefore group embeddedness, and hence appropriate-

The distinction has been independently developed in economics, VANBERG and BUCHANAN in Journal of Theoretical Politics (1989), and in political science, YEE in International Organization (1996).

The same wording is also to be found in one of the competing conceptions. MARCH and OLSEN in International Organization (1998) 952 speak about "ideational factors (such as norms and identities)". Ibid. in

205 This is made explicit Ibid. in 951.

206 Of the many voices see GIDDENS Constitution of Society (1984); MARCH and OLSEN in International Organization (1998) 949, 951; JAKOBS Norm, Person, Gesellschaft (1999) .

207 SMITH Moral Sentiments (1790)

208 See e.g. BOHNER in Hewstone and Stroebe (2001) 242 with refs.

209 Fairness is one of the key topics of experimental economics. Impressive HENRICH and BoYD Economic Man (2001) ; for an example from field-work see FREY and OBERHOLZER-GEE in Frey (1999)

210 An illustrative example is to be found at FREY Human Behaviour (1999) 166: in a snowstorm, snow shovels become an extremely scarce good. $83 \%$ of subjects in an experiment considered it unfair if the local store raises the price, although this would be a perfectly rational reaction within the rational choice framework. This is the basic tenet of SCHLICHT Custom (1998)

212 For an overview see DiCKENBERGER, GNIECH and GRABITZ in Frey and Irle (1993) 
ness, is not the only means for coordinating behaviour among hierarchists. Hierarchy can switch to grid, and it predominantly does. Egalitarians, however, have no substitute for appropriateness and identity at their disposal.

The belief challenge is likely to have an impact on the governance of egalitarian actors, or their members, by incentive. Their belief system does not make it self-evident for them to swiftly react to changes in the opportunity structure, to begin with. Even worse, such changes are likely to be interpreted as individualistic attacks on the egalitarian identity. In that event, active resistance is a likely outcome. Attempts of egalitarians to inflict damage on the intervening outside actor can be the result. Or a process of creatively diverting the governance impulse into its opposite can be triggered.

Governance by order does not fare better. Again, egalitarians are not likely to take hierarchical intervention as self-evident. Due to their characteristic low degree of corporatisation, this is a severe limitation to governing egalitarians. For it is not likely that the intervention will be quickly transformed into a routine, or integrated into egalitarian morality. Another way of making the point is: Egalitarians are likely to lack generalized trust in hierarchic intervention. The way hierarchic rules are generated, namely relying on the best expertise available, does not provide them with legitimacy in egalitarian circles. On the contrary. Egalitarians will have a positive preference against using this institution to generate rules and a preference against applying rules via an administrative institution.

The logic of appropriateness is not only a direct challenge to outside governance, it is also an indirect challenge. The second effect plays itself out, once governance targets members who are less strictly embedded in an egalitarian movement. Were they alone, outside actors might be able to override their individual belief systems. But these individuals anticipate the reactions of their peers, once they give in to outside pressure. The effect surges if these individuals foresee that more zealous group members will consider their giving in inappropriate. Since the zealots have shaming and expulsion at their disposition, the followers will resist the outside pressure.

\section{Exploiting Foreign Beliefs}

As with the group challenge and the cognitive challenge, outside actors can react to the belief challenge by adapting their form of intervention to what they know about the belief structure of their addressees. In a way, egalitarians are excellent regulatory targets. Their internal belief system trains them to think in categories such as social betterment, solidarity or fairness. If the outside actor succeeds in presenting the regulatory issue in such terms, chances are that egalitarians come on board without any resistance whatsoever. This will be easier to do for hierarchists than for individualists. Hierarchists in democratic countries are accustomed to giving reasons for the rules they design anyway. It is not too demanding to add moral considerations to a rule crafted by experts. Defining what experts see as public bads in terms of public enemies natural disasters or moral deprivation isn't difficult either. Such a bivalent approach may also help if 
egalitarian followers need support countering zealots. The risk of shaming and expulsion may be brought under control if the outside actor also offers language that makes abiding by the external expectation acceptable internally.

While all this is feasible, it is not easy to implement. For it presupposes that the outside actor can reliably predict how the egalitarian movement will perceive the normative demand, or the intervention. Obviously, intervention into markets faces the same problem. But due to workable competition, firms have little leeway in ignoring pre signals. What the logic of appropriateness means in concrete terms, however, is significantly less clear in advance. This is so, since defining appropriate behaviour is itself a social endeavour. The outside intervention confronts egalitarian communication with a new task. Only after the ensuing internal discourse generates a consensus can the reaction be assessed. This happens typically after, not before, the fact.

Outside actors can not only increase the chances for success by exploiting the substantive egalitarian logic of appropriateness. Alternatively, or cumulatively, they can try to conform to egalitarian procedural norms. Giving the egalitarian movement an opportunity to discuss the issue before the outside actors take action is already a step in this direction. True arguing goes even further down that path. It provides egalitarians with a true opportunity to be heard, to get responses, even to influence the shape and the direction of the intervention.

A related way of making the point will be clear if one understands why a way of life leads to perceiving a particular act of intervention to be legitimate. Legitimacy theory has long distinguished between input and output legitimacy. The former means those in power are formally accountable to the governed. In democratic countries, this is provided by general elections, and by a chain of legitimacy running from the elected representatives down to any form of state intervention into individual freedom. Output legitimacy relies on the quality of problem-solving. If experts demonstrate that the intervention does indeed serve social betterment, and why, this generates legitimacy. ${ }^{213}$ Cultural theory makes it plausible to interpret input legitimacy as individualistic. In individualistic logic, governance cannot be legitimate if it cannot be traced back to the will of individuals. Likewise, output legitimacy can be interpreted as hierarchic. In accord with this interpretation, the logical third step is missing: Egalitarian legitimacy. Its procedural currency is participation. And its substantive currency is fairness. Adding these elements to their interventions should thus considerably increase the chances for outsiders to effectively govern egalitarians.

Conveying fairness to the intervention is also necessary in a very down to earth perspective. Egalitarians should be fairly easy to convince that a true social problem must be fixed. But within their logic they will expect all those who profit from the intervention to contribute a fair share. Put the other way round: if egalitarians expect to be the only ones who sacrifice individual interest for the common cause, they are not likely to do so.

213 EASTON Systems Analysis (1965) ; the category is central to the work of FRITZ SCHARPF, see e.g. SCHARPF Governing in Europe (1999) 


\section{Changing Foreign Beliefs}

As with the other challenges, for the belief challenge there is also a two level response. On the first level, the outside actor tries to change the egalitarian belief system in a way conducive to its own ends. On the second level, the outside actor exploits the new beliefs.

In a radical way, this would mean siphoning members away from an egalitarian movement, or destroying it altogether. These options have already been considered under the heading of the group challenge. Hierarchists have another, less radical option. They can try to expose the members of an egalitarian movement to competing solidarities. On theoretical grounds, this is feasible, since the hierarchic way of life also ranks high on the group scale. Practically speaking, this means pitching national, regional or municipal solidarity against the in-group solidarity of egalitarians. The strategy dates as far back as Jean Jacques Rousseau. In his contrat social, he opposes good volonté génerale to bad volonté de tous. Solidarity with the larger group must override solidarity with the smaller one, lest society is to fall apart into factionism. ${ }^{214}$ One need not be that radical. Making the tension between the two solidarities visible may be enough to make egalitarians more responsive to outside interventions.

Apart from this direct route, there is also an indirect one. The outside actors would not directly impinge upon the egalitarian self definition of appropriateness. As with cognitive governance, they would rather confront the egalitarian movement with a surprise by changing the environment. That way they could hope to trigger an internal dynamics that results in a change of the belief system.

\section{The Autopoiesis Challenge}

Autopoiesis is a concept from systems theory. Cultural theory and systems theory differ in a considerable number of respects. Nonetheless, the core ideas inherent in the concept of autopoiesis carry over to governance across ways of life (section 1 below). Specifically, one may speak about egalitarian autopoiesis (section 2). This conceptualisation makes sense, since systems theory has for long faced the governance challenge. To a considerable degree, the responses given in that context carry over to governing the egalitarians from without (section 3).

\section{Autopoiesis}

Systems theory is about communication, not about individuals. ${ }^{215}$ Communication is expected to take place within social contexts that exhibit self-referentiality. ${ }^{216}$ The term means that the sys-

214 RousSEAU Contrat Social (1763)

215 LUHMANN Ökologische Kommunikation (1986) 24; these and the following citations are culled from this, seemingly tangential work of LUHMANN. But none of his other numerous books presents his theory in a similarly succinct way. 
tem itself, by communication, constructs its environment. ${ }^{217}$ In so doing, it also constructs itself. $^{218}$ Society is thus sensitive to its environment, but operationally closed. ${ }^{219}$ It is "autopoietic" ${ }^{220}$ It is by the social exercise of communication ${ }^{221}$ that society decides whether what happens in its environment is understandable or irrelevant noise. ${ }^{22}$ Society thus autonomously decides whether a change in the environment has relevance. The decision depends on the ability to integrate the change into internal communication. ${ }^{223}$ Society is primarily driven by the maintenance of autopoiesis, not by the degree of adaptation to the environment. ${ }^{224}$ All this does not only hold for society at large. It carries over to subsystems within society, like the political system, the economy, the legal system, science, the arts, the education system and so forth. ${ }^{225}$

If society and its subsystems are as systems theory says they are, this is not an evolutionary defect. On the contrary. Autopoiesis of the subsystems is the precondition for handling an exponentially larger degree of complexity. ${ }^{226}$ Autopoiesis allows the subsystem to dramatically reduce complexity internally, ${ }^{227}$ and thus to exist and reproduce in a much more complex environment. $^{228}$

The concepts from systems theory introduced so far can be applied to competing ways of life as well. They also start from communication, not from the individual. They are equally constructivist in nature. By their internal discourse, they decide which elements of the environment have relevance, and which do not. The distinction between noise and relevance can be mapped onto the concept of surprises as presented earlier. A way of life can and will ignore a large amount of the complexity inherent in the environment. But it can face surprise, and then integrate the new observation into its internal communication. ${ }^{229}$ Above all, the basic normative tenet of systems theory carries over to cultural theory. If outside actors try to ignore autopoiesis, dedifferentiation ensues. Society at large loses some of its ability to handle complexity. ${ }^{230}$

Despite these parallels, a good number of differences between systems theory and cultural theory remain. Each of the two approaches has its own rigidity, but in different places. Cultural theory limits the number of ways of life to precisely four. The number of systems, or of subsystems

225 An overview of these sub-systems is given by Ibid. 101-201.

226 Ibid. 45, 48 and passim.

227 Ibid. 24.

228 Ibid. 33.

229 The following quote by Ibid. 40 does almost sound as if it were culled from cultural theory: "dass das System seine Selbstreproduktion durch intern zirkuläre Strukturen gegen die Umwelt abschließt und nur ausnahmsweise, nur auf anderen Realitätsebenen, durch Faktoren der Umwelt irritiert, aufgeschaukelt, in Schwingung versetzt werden kann”. 
within a society, is not limited by systems theory. Conversely, systems theory draws a strict line between what it calls code and what it calls programme. ${ }^{231}$ Each subsystem is defined by a binary code: ${ }^{232}$ legal and illegal for the legal system; having money or not for the economy; having power or not for the political system, and so forth. The code only determines what type of questions are asked in the communications of a subsystem. What answers are given depends on programmes, i.e. on normative goals. Systems theory allows a subsystem to choose whatever programmes it deems fit. It is precisely the categorical openness of programmes that allows subsystems to react to their environment. ${ }^{233}$ This is the total opposite of cultural theory, which posits that normative goals are clustered into the four ways of life.

Systems theory is even conspicuously sceptical about what drives cultural theory: deep normative convictions. It denunciates egalitarian movements as premodern moralism, not fit for the contemporary complex world. ${ }^{234}$

What is offered here is thus not the simple application of a concept from systems theory to a problem of cultural theory. It rather is an attempt to blend both theoretical corpuses. As is characteristic for blending, not all elements carry over from one context to the other. But blending helps highlight aspects in the target context that would not be visible otherwise. ${ }^{235}$ Cultural theory so far has no language for the cost of one way of life impinging on the other. The concept of autopoiesis from systems theory helps cultural theory to ask the right questions in this respect.

\section{Egalitarian Autopoiesis}

The idea of autopoiesis may well fit all four ways of life. Individualists or hierarchists have no lesser need to stabilize their way of life by conducting a discourse explaining the world their way. But due to the characteristic preference for governance tools, it is less visible to outside observers how much the other ways of life rest on such internal discourse. For egalitarians this is patent. For them, communication is not only necessary for laying the conceptual foundations. It also is their prime tool for actual governing. In the pure case, a collective actor gains its existence by nothing else than shared communication. By communication, it is determined who is a member, and who has overstepped the limits of the logic of appropriateness. An exchange of public statements of belief is what ties the egalitarian actor together. 


\section{Governance Despite Autopoiesis}

The founding father of systems theory, Niklas Luhmann, did not believe in governance at all. To him, outside intervention was futile, even noxious exercises in disregarding autopoiesis. ${ }^{236}$ Some of his successors are more liberal. They also insist on autopoiesis, both in factual and in normative terms. But to them, autopoiesis is no more than a serious challenge to governance. ${ }^{237}$ In line with earlier parts of this paper, an outside actor has two strategies: it can leave autopoiesis as it is, and try to adapt its reaction to it. Systems theorists call this contextual governance (section a below). Or it can engage in two level governance and reduce autopoiesis in preparation for the actual intervention. Systems theorists call this partial dedifferentiation (section b).

\section{a) Contextual Governance}

The basic idea of contextual governance is straightforward. If autopoiesis is to be respected, changing the environment such that a realignment of the internal construction of reality becomes likely is how governance must be done. ${ }^{238}$ This directly translates into the language of cultural theory. Contextual governance can be interpreted as artificially creating surprises for a way of life. ${ }^{239}$ Of course, autopoiesis implies that the outside actor cannot fully predict the reaction of its target group. Contextual governance is clearly probabilistic, not deterministic. But the better the outside actor understands the internal logic of its egalitarian addressee, the more educated its guesses should be.

Contextual governance is indirect per definition. But the outside actor has two possible ways to change the environment. Employing the more direct alternative, it can assess the responsiveness of the egalitarian actor to several changes in the environment, and choose them accordingly. In the more indirect approach, the outside actor can strengthen one of the normative competitors of egalitarians. If this is done, the autopoiesis challenge doubles. The favoured way of life must pick the opportunity. The target way of life must react to the activities of the favoured way of life triggered by the outside actor. The obvious price of this strategy is a loss of predictability. But the outside actor may gain a greater impulse, or increase its likeliness of being effective. In practical terms government might give market actors additional institutional input, expecting that they use it against the egalitarians. Alternatively, market actors might give government more money, or rally with government officials in their fight against egalitarians.

236 LUHMANN Ökologische Kommunikation (1986) 63; LUHMANN in Zeitschrift für Rechtssoziologie (1995).

237 Since this is not a paper on systems theory, I confine the following to the work of GUNTHER TEUBNER, which lends itself best to being carried over to cultural theory.

238 TEUBNER Recht als autopoietisches System (1989) 83-87; see also TEUBNER in Archiv für Rechts- und Sozialphilosophie (1982); not the term, but the idea of contextual governance is also prominent in WILLKE Die Entzauberung des Staates. Überlegungen zu einer sozietalen Steuerungstheorie (1983) part 4. 


\section{b) Partial Dedifferentiation}

Autopoiesis is a social construct. To a considerable degree, outsiders can just ignore it. Government can put members of an egalitarian actor in jail if they do not exactly abide by the letter of an order. Likewise, firms can exploit the fact that no egalitarian actor is fully self-contained. They can strategically buy those resources the actor needs for its subsistence. None of these radical strategies is fool proof. The Internet in particular is full of examples of government and commerce failing altogether. But feasibility should not be the prime concern for outside actors. The real price they would pay for such rude action is a loss of opportunities for their own way of life. For all ways of life need the others as a sort of an infrastructure. It has already been demonstrated why this statement holds for the egalitarian infrastructure of the Internet.

As already mentioned, systems theory calls this effect dedifferentiation. ${ }^{240}$ But systems theory rightly does not see differentiation as an absolute. Rather, subsystems are to a different degree resonant to impulses from others. ${ }^{241}$ Systems theory even allows for what it calls structural coupling. The term characterizes a particularly high degree of resonance by one subsystem for signals from another. For instance, the political system needs money to cover the regulatory costs, to provide public goods, and to pay subsidies. It takes this money out of the economy by way of taxes. Thereby, the political system becomes dependent on the success of the economy. ${ }^{242}$

Some systems theorists turn these insights into recommendations for policy-making. They allow for interventions aimed at making a target subsystem more resonant to governance impulses. ${ }^{243}$ The idea carries over to the governing of the egalitarians from without. Actors embedded in different ways of life can engage in making the egalitarians more resonant to governance attempts. But the caveat carries over as well. This is a risky endeavour, in that it inevitably also means partial dedifferentiation. If they overdo, the outsiders risk losing or at least damaging the egalitarian infrastructure.

The available tools for making egalitarians more resonant have already been discussed under different headings. The outside actor can specifically target egalitarian followers, aiming at an internal dynamic that siphons powers away from the zealots. For the purpose, it can give exit options, expecting that they translate into more voice internally. The outside actor can also offer advantages to the egalitarian movement as such, or threaten it with disadvantages, both conditional upon a greater willingness to listen to governance attempts.

240 LUHMANN Ökologische Kommunikation (1986) 207.

241 Ibid. 40.

242 Cf. Ibid. 178.

243 TEUBNER Recht als autopoietisches System (1989) 101, see also 96. 


\section{The Cultural Balance Challenge}

The foregoing has been an attempt to decompose the cultural balance challenge. This exercise has generated a better understanding of the challenge, and logical responses to its elements. In this section, the challenge shall be faced up front. A key concept of welfare economics is market failure. In analogy to this terminology, unbalanced egalitarianism can be characterized as group failure (section 1 below). Normatively speaking, it generates a balancing task (section 2). Each of the three active ways of life has its own view of how such rebalancing should best be brought about (section 3). Each of these approaches can also impose itself on reluctant competing ways of life (section 4). But a more neutral balancing technology may be better. This explains, why balancing in practice is so often entrusted to hybrid approaches, mixing elements from several ways of life (section 5).

\section{Group Failure}

Welfare economics is normative. It explains why, under standard conditions, markets do a perfect job of allocating scarce goods, and of bringing innovation about. But welfare economics also analyses the conditions under which markets fail, and suggests outside acts of intervention. In line with a cultural theory perspective, market failure is a failure of the individualistic way of life. Since cultural theory posits that any way of life left alone leads to disaster, it logically must also envisage a failure of the hierarchic way of life. Again, economists will applaud. For public choice for decades claims that government failure is no less likely than market failure. The logical third balancing mistake, however, is rarely discussed. Egalitarianism can also go astray. In order to stay in line with the terminology familiar to economists, this balancing problem can be called group failure.

\section{The Balancing Task}

The normative goal is thus rebalancing. The term should be taken at face value. If markets fail, welfare economists do not call for the abolition of markets. On the contrary, they search for reactions that give the coordinative power back to the market. A classic response is a pigouvian tax, i.e. a realignment of relative prices such that individual and social benefit once again coincides. Likewise, if hierarchists diagnose government failure, they do not call for the abolition of government. They rather recommend rebuilding government such that it does a better job. Group failure is no different in this respect. There is no reason to throw the baby out with the bath water. Reconstructing egalitarian movements such that they no longer fail is the appropriate strategy.

The normative goal is one of balancing. This opens up an avenue for a more indirect remedy. An unbalanced situation can also be improved by tilting the balance on the opposite side. Rather than weakening the egalitarians, those ways of life that currently have too little impact can be 
strengthened,. This strategy has one advantage: The disfavoured ways of life can adopt it on their own initiative. For instance, in the Internet case, government can seize the new opportunities for electronic power. And firms can seize the new opportunities for designing their own, customized institutions.

\section{The Three Archetypes of Balancing}

Cultural theory convincingly explains why the different ways of life must be balanced. But it has no theory about how rebalancing can be brought about if a society has got out of balance. Cultural theory, as it stands, is not about policy advice. The following is an attempt to fill the lacuna. It fleshes out three balancing archetypes. It is no coincidence that each of them follows the logic of one of the three ways of life. Organising co-existence is the egalitarian way to achieve balancing (section a below). Negotiation is the individualistic way (section b). And governance is the hierarchical solution (section c). The typology implies that the mechanism used for rebalancing might or might not match the internal logic of the addressee (section d).

\section{a) Organising Co-Existence}

In the reference text of cultural theory, balancing just happens. "Change is essential to stability". 244 "Stability is not like being in limbo, suspended, motionless, with no energy required. Rather, stability requires constant energy, running, as it is said, just to stay in place”. 245 "Always in disequilibrium, always on the move, never exactly repeating itself, always having a definite shape, yet never staying in same shape, the system itself is indestructible". ${ }^{246}$ The metaphor of a flock of starlings captures the idea: "Since there is no generalissimo starling to tell each bird when to move and where to move to, individual starlings must be responding to some easily read signals that are built into their relationship with their fellows."247

The quotes are telling. Hiddenly, cultural theory as it stands has an egalitarian bias. It accepts the other solidarities out there. But when it comes to balancing the competing solidarities out, it wants to have it the egalitarian way: every single individual fully engaged in a man by man fight for social betterment. At the meta level, either society adopts egalitarian mores, or it does not.

The egalitarian way of balancing the competing solidarities is feasible. Evolutionary game theory even offers elegant models for describing the process. ${ }^{248}$ Computer simulations in what is now normally called “agent based modelling” generate interesting, often even unexpected insights. ${ }^{249}$

244 ThOMPSON, ELLIS and WiLDAVSKy Cultural Theory (1990) 80.

245 Ibid. Cultural Theory 66; see also THOMPSON, ELLIS and WiLDAVSKY Cultural Theory (1990) 80: "Stability without change is like trying to balance oneself on a bicycle without turning the pedals”.

246 THOMPSON, ELLIS and WILDAVSKY Cultural Theory (1990) 86.

247 Ibid. Cultural Theory 85.

248 An impressive application to the problem of competing solidarities (named differently, however), is to be found at ARCE and SANDLER in Journal of Institutional and Theoretical Economics (2003).

For an overview see TESFATSION in Journal of Economic Dynamics and Control (2001). 
Psychological research into persuasion makes it possible to understand how partisans of other ways of life can indeed be won over to, or at least made more responsive to competing needs. ${ }^{250}$

\section{b) Negotiation}

The individualistic way of balancing competing solidarities is through negotiation. ${ }^{251}$ The ways of life come to the real or imaginary negotiation table with their predetermined meta-preferences. Rational choice theory can analyse such negotiations easily. The basic prediction is that the outcome depends on breakdown values. No negotiation partner is forced to agree. He will not if the status quo ante is more favourable. ${ }^{252}$ Since cultural theory demonstrates that an unbalanced society is, in the long run, detrimental to all ways of life, the negotiation range should be sufficiently large. But cultural theory also posits that there are four ways of life, with only three of them being active. This allows for strategic interaction, and the building of different coalitions. Rational choice oligopoly theory demonstrates why this is a thorny setting for negotiations. ${ }^{253}$ In game theoretic terms, balancing is a positive sum game. But is has several equilibriae. And these equilibriae have different distribution effects. ${ }^{254}$

\section{c) Governance}

The hierarchical way of bringing about a balance between competing ways of life is through governance. A benevolent central authority intervenes on behalf of society at large. It does so based on the best expertise available. In this case, the expertise would be taken from cultural theory. Cultural theory would thus provide the legitimation for central intervention. Hierarchists would introduce a formal procedure, and entrust an organisation with the balancing task. The quintessential institution of the hierarchical way of life is government. But an independent balancing authority, following the model of institutions like the central bank, would also be in line with hierarchist thinking. ${ }^{255}$

\section{d) Match and Mismatch}

The foregoing reveals an obvious problem. Balancing must be carried out across ways of life. But each way of life has a meta-preference for doing it its own way. Using any of these three balancing technologies means bundling partial match with predominant mismatch. Individualists are willing to trade everything, as long as they get enough in exchange. Hierarchists are willing

250 For an overview see TrenHOLM Persuasion (1989)

251 Cf. MARCH and OLSEN in International Organization (1998) 950: negotiation fits the logic of consequentialism.

252 An easily accessible summary is to be found in KNIGHT Institutions and Social Conflict (1992) Chapter 5.

253 Comprehensive TIROLE Industrial Organisation (1988)

254 For a highly stimulating application of game theory to the understanding of such problems see HOLZINGER Common Goods (2003)

255 An illustrative piece of such thinking is MAJONE in Journal of Institutional and Theoretical Economics (2001). 
to give in if they can be convinced, by sound expert argument, that the reform leads to social betterment. Egalitarians are willing to treat other ways of life fairly if they trust the competitors to reciprocate. Choosing any of these ways violates the fundamental expectations of the two other active ways of life. Specifically, egalitarians will oppose negotiations, since a precondition for them would be a high degree of corporatisation. ${ }^{256}$ And negotiations would force them to trade externally what they internally perceive as holy convictions or inalienable goods. ${ }^{257}$ And balancing by governance would force egalitarians to accept formal authority, based on input legitimacy, rather than participation. And they would have to give in to power based on expert opinion, rather than on grass roots engagement and open discourse.

\section{Imposed Balancing}

In the previous section, the position of cultural theory on balancing has been interpreted as having a hidden egalitarian bias. Another way of interpreting the many citations given at the beginning of the last section is the following: don't worry, nature will do the balancing anyhow (section a below). This optimism is questionable. It is highly plausible that society at large is better off if it sees to it that rebalancing takes place early enough. This can be done by imposing one of the three archetypes analysed in the last section (section b). But if balancing is imposed by human design, another, neutral balancing technology becomes even more desirable (section c).

\section{a) The Role of Nature}

The flock of starlings is an evocative metaphor. But why does each starling permanently rearrange its own position to coordinate with the movements of its peers? In the case of starlings, the most likely answer is: It is genetically programmed to do so. But the genetic wiring of human social behaviour is not very deterministic. Many observers even see the fairly high malleability of behaviour to be the key factor in explaining why humans dominate the other species. ${ }^{258}$ Of course, culture could step in and make it difficult, if not impossible, for individuals to eschew socially beneficial balancing efforts. ${ }^{259}$ But it seems highly optimistic to think that the natural and cultural endowments of man are sufficient in themselves to bring a healthy degree of balancing about. Put differently, in the very long run, the suppressed ways of life may find their way back to the surface. But during the long intermission society may well be locked into a highly unbalanced situation.

256 See above IV 5 b.

257 On inalienability see RADIN in Harvard Law Review (1987).

258 This is one of the key topics of evolutionary psychology. For an overview of the field see LALAND and BROWN Evolutionary Psychology (2002)

259 Understanding the cultural, as opposed to the genetic, component in human behavioural programmes drives the anthropological research on ultimatum games. For the impressive outcomes of this research see HENRICH and BOYD Economic Man (2001) 
There are many ways of explaining why this might happen. Game theorists would apply the concept of the Nash equilibrium. A socially sub-optimal state of affairs can well be the relative best response of each way of life, given the moves of the competing ways of life. ${ }^{260}$

Transaction cost economics explains log-in with sunk costs. ${ }^{261}$ Applied to the co-existence of ways of life, this would mean: one or several ways of life have made investments that are rational only if the previous balance persists. In an alternative, socially more beneficial balance, the investment would no longer make sense. The investment cost would be sunk.

Network economics explains lock-in dynamically. A technology becomes path dependent if too many potential users have adopted it. In essence, this is also a sunk cost argument. The switching cost from one technology to another seems too high for individual users. But the problem is compounded by the fact that a competing, better technology can only outperform the existing one if it can credibly promise new users to quickly generate the critical mass. ${ }^{262}$ At first sight, this doesn't seem to carry over to the balancing of competing ways of life. For cultural theory posits that there are only four ways of life, with only three being active. But the logic of network economics applies once the competing ways of life are no longer assumed to react uniformly. If balancing them is an exercise of individual partisans of these solidarities, one balancing technology can well obey the axioms of network economics. If so, society at large can be stuck with one historic balancing technology.

Another explanation takes the term "balancing technology" literally. The Internet is precisely an example of this. As mentioned, one can interpret the technical standards underlying the Internet as a hardwiring of the egalitarian way of life. ${ }^{263}$

Sociological approaches would add the possibility of institutional embeddedness. They stress that, once set up, institutions lead their own, independent life. Even if their founders no longer stand behind them, they can still determine social interaction for an extended period. ${ }^{264}$

\section{b) Imposed Balancing}

From the counterfactual perspective of a social planner, it would thus be desirable to impose balancing early enough. But how can this be done in a reality that has no outside actor hovering above the struggling ways of life ${ }^{265}$ A first, tentative answer is: each way of life can use its own

260 Basic NASH in Econometrica (1950); NASH in Annals of Mathematics (1951).

261 WILliamson Institutions of Capitalism (1985) Chapter 2.3.

262 Basic DAVID in van Ark (1997)

263 See above II 3.

264 Basic MARCH and OLSEN Rediscovering Institutions (1989)

265 Actually, in its original version, cultural theory had such a fifth solidarity, called the one of hermits, THOMPSON, ELLIS and WiLDAVSKY Cultural Theory (1990) 8, 29-33 and passim. In more recent versions, however, this fifth solidarity has disappeared, see e.g. THOMPSON in Engel and Keller (2000) .This is why it has not been mentioned throughout this paper. At any rate, even in the earlier version, the hermit has been defined as being pure observer, not an actor, THOMPSON, ELLIS and WILDAVSKY Cultural Theory (1990) 10. It can therefore not step in to restore the lost balance. 
resources for the purpose. Egalitarians can start a man by man fight against those who adhere to different ways of life. Hierarchists can mobilize the sovereign powers of government for the purpose. And individualists can offer those groups abiding by other ways of life, or their individual members, a deal.

These strategies can work out. For centuries, sovereign states have been willing to negotiate with their peers over exchanges, and even over rules, internationally. More and more states also negotiate with individuals ${ }^{266}$ and with social movements, and have less and less recourse to their sovereign powers. ${ }^{267}$ Allegedly individualistic firms often stay in a country much longer than the return of their local investments would make rational. They thus give in to quite some hierarchic intervention, even if it is costly. And they increasingly respond to egalitarian demands, as demonstrated by the mushrooming green alliances. ${ }^{268}$ Likewise, egalitarians might be willing to accept some governmental intervention in the interest of rebalancing. Or they might be open to doing deals externally. The practical possibilities have already been treated earlier under different headings. In a deal, outside actors might offer the egalitarians resources they care about internally. They might also credibly threaten them with sufficiently critical disadvantages. Alternatively, government might strive to bring egalitarian action under the shadow of hierarchy.

\section{c) A Neutral Balancing Technology?}

It is thus feasible to take the balancing technology preferred by one of the competing solidarities. Yet it might still seem attractive to seek out another, neutral way of balancing the competing solidarities. If cultural theory gets it right, this neutral technology cannot be at the level of solidarities. There is nothing else but grid and group at this level, resulting in the four ways of life.

One might think that the different level is conflict. An observation from legal practice points in that direction. In principle, under the rule of law, the courts have no open discretion. It is their task to apply the law as it stands. In court practice, however, judges often deviate from this principle. They do so since they are convinced that applying the law would not solve the conflict of the parties before them. In order to make this consistent with their procedural obligations, they present the draft of a settlement to the parties. If the parties agree to that, it is their authority, not the authority of the court, that is exercised.

Along these lines, one may ask whether neutrality might be generated if balancing is replaced by managing conflict between the competing ways of life. One can push the idea even further. For in practice conflict is often not eradicated altogether. Instead, it is managed by being institution-

The question has long been discussed by lawyers. For a consistently hierarchic, but almost anachronistic voice in German law see BURMEISTER in Veröffentlichungen der Vereinigung der Deutschen Staatsrechtslehrer (1993). The much more impure position of the legal mainstream is to be found in KREBS in Veröffentlichungen der Vereinigung der Deutschen Staatsrechtslehrer (1993).

268 For an example see LIVESEY in Journal of Business Communication (1999). 
alised. The conflict remains. But its detrimental power for the conflicting parties, and for bystanders, is reduced by drawing clear lines. ${ }^{269}$ Disputes are submitted to court. ${ }^{270}$ Social norms impose the formalities of a dual on an honour based society. ${ }^{271}$ Workers are allowed to strike, but forced to go through a long series of procedural steps before and while they do. ${ }^{272}$ Likewise, one could conceive of procedural rules that make balancing a permanent endeavour, rather than an eruptive event.

But what works well for legal practice seems less appropriate for the interaction among ways of life. Not that anything would be wrong with a piecemeal approach. But conceptually it seems difficult to distinguish between balancing and conflict. The very message of cultural theory can be couched in conflict terms. It then reads: permanent conflict among ways of life is a good thing. At closer sight, balancing and institutionalising conflict thus turn out to be two names for the same thing.

\section{Hybrid Approaches}

Pure neutrality is thus not within reach. This does not mean, however, that balancing can only be done in one of the three archetypical ways described above. There are many hybrid approaches, mixing elements from two, or even from three of the active ways of life. Cultural theory does even have a term for them. It calls such approaches clumsy. ${ }^{273}$ The unappealing term serves as a healthy reminder. The important thing with balancing technologies is not their conceptual purity. It is their performance that counts. Many cultural theorists even make it their business to write case studies carrying this point home. They demonstrate that clever muddling through is often smarter than employing a grand theoretical design that fails miserably in practice. ${ }^{274}$

It follows from the foregoing that any analysis of hybrid balancing technologies can only be illustrative. Three characteristic approaches shall be highlighted here: arguing (section a below), the law (section b) and addressing individuals as multiple selves (section c). If one wants to impose some order on them, one might interpret arguing as an extension of negotiations, the law as an extension of hierarchy and addressing individuals as multiple selves as an extension of organising co-existence. That way, arguing would represent soft individualism; the law, soft hierarchy; and addressing individuals as multiple selves, soft egalitarianism. There is a kernel of truth in these categorisations. But as said before: one should be careful not to impose rigidity on tools that are meant to overcome the problems generated by excessive rigidity.

269 ENGEL in Journal of Institutional and Theoretical Economics (2003a) section 4; EGEBERG Organisational Approach (2002) speaks of "patterned” conflict instead.

270 FARNSWORTH Self-Serving Bias (2003) .

271 O'NEILL in Journal of Institutional and Theoretical Economics (2003)

272 PosNer in Journal of Institutional and Theoretical Economics (2003)

273 See e.g. SHAPIRO in Southern California Law Review (1988).

274 A fine example is VerweIJ A Snowball against Global Warming. An Alternative to the Kyoto Protocol (2001) 


\section{a) Arguing}

In the above, negotiation has been identified as the individualistic style of balancing. This statement is seemingly contradicted if arguing is now introduced as a hybrid approach. For arguing is a way of negotiating. The apparent contradiction disappears if the concept of negotiation is unpacked. For the sake of clarity, the purely individualistic component can be called bargaining. All come to the bargaining table with predetermined preferences, and with fully defined property rights. But in reality, negotiations are rarely as limited as that. On the proverbial Turkish bazaar, the trader portrays the shabby merchandise as if it were a marvel from the thousand and one nights. He praises the unheard of beauty of the buyer's wife. And he draws a gloomy picture of ruin if he squanders his goods for such a trifle sum. This is not just for show. The owner of this tatty little shop tries to transform a routine transaction on the spot market into a passionate affair.

In the case of the shop keeper, not many tourists are trapped these days. Some take it as a game and pay the exaggerated price in exchange for a good performance. The others go by and make their deals in a more neutral environment. But the example highlights the power of words. This power can be exploited in the interest of balancing competing ways of life. In the interest of winning egalitarian support, the other ways of life can use the accompanying words to create a mutual sense of trust and fairness. They can ask the egalitarians for their position on the issue, and make an effort to say in their words why there is a need for rebalancing.

A hierarchic element can also be introduced into negotiations. Government can withhold unilateral interventions as long as possible. It can thus transform its sovereign powers into bargaining chips. This is what happens in the already mentioned bargaining under the shadow of hierarchy. ${ }^{275}$ And arguing allows government to bring the component of expertise of hierarchy to bear. Rather than just transforming the result of experts' work into an order, government has an opportunity to explain the underlying reasons to potential addressees. ${ }^{276}$

\section{b) The Law}

In the above, governance has been characterised as the mode of balancing that matches the hierarchic way of life. The law is the classic governance tool. As with negotiation, it may therefore appear contradictory to present the law as a hybrid approach. Yet for reasons similar to those that apply to arguing, the law can legitimately be interpreted as a "clumsy" tool. ${ }^{277}$ For governance by law is fuzzy on purpose. ${ }^{278}$ Legal governance is text-bound. The authorities entrusted with its application listen to the addressee and explain themselves. The addressee therefore knows what the law is heading for. The discourse reminds the addressee of normative expectations. ${ }^{279}$ It also

275 See again SCHARPF Games (1997) 201-204.

276 On these, and many more, facets of arguing see RISSE in International Organization (2000).

277 As is explicitly done by SHAPIRO in Southern California Law Review (1988); see on the following ENGEL in Rengeling (2001a) and ENGEL The Role of Law in the Governance of the Internet (2002c)

278 Cf. MAYNTZ in Mayntz (1983) 69-69.

279 More from BoHnET Kooperation (1997) 
provides the addressee with an opportunity to raise concerns about the adequacy of the rule. By its discursive character, the law has access to the cognitive models on which the addressees base their view of the world. The law can occasionally even exploit this opportunity to reshape the preferences of its addressees.

\section{c) Addressing Individuals as Multiple Selves}

In the above, organising co-existence has been said to be the egalitarian way of balancing the competing solidarities. In its purest form, egalitarianism has no formal organisation. Consequently, a man by man fight is the way of balancing that comes closest to the egalitarian ideals. It may therefore appear surprising to present an approach as hybrid that precisely targets the convictions of individuals. Yet again, the surprise disappears at closer sight. Egalitarianism is not just about individual convictions. It is about individuals holding egalitarian convictions. There are some who indeed are to a very large extent just egalitarians. But most people are not that one-sided. They may hold egalitarian beliefs in family matters and with respect to environmental issues. But when seeking a new job or buying a new car, they may well behave like hard-nosed individualists. And when it comes to drug abuse or vandalism, they may well think that the police should step in. Most people thus do not exclusively adhere to one way of life. They typically are multiple selves, holding different, perhaps even inconsistent beliefs in different areas of their lives.

This characteristic inconsistency in individual belief systems can be exploited to rebalance ways of life. For outsiders can try to appeal to those sides of a personality that are more resonant than the solidarity disregarded in the issue at hand.

\section{Lessons for the Internet Case}

The theoretical part of this paper has covered a lot of ground. But any theory must limit the issue. The paper has done so by stylising the facts. It has looked at a situation that is out of balance exclusively because of the preponderance of egalitarianism. The egalitarian element has been assumed to be standard in any possible respect. This simplification captures a serious problem of Internet governance. Before drawing normative conclusions, however, the most important other specificities of the case must be laid out. Some are good news for those who want to bring about the rebalancing of the solidarities (section 1 below). Others compound the challenges for outside actors (section 2). In light of these specificities of the case, tentative normative conclusions can be drawn (section 3). 


\section{The Easy Part}

Two elements of the Internet case make rebalancing easier than in many other cases. The Internet egalitarians are a fairly well defined and cognisable group (section a below). And the missionary element is at most weak (section b).

\section{a) No Mixed Target}

Normally, rebalancing is not the only governance task. It is combined with the need to lay institutional foundations for social interaction, or to internalise externalities. In that event, it is difficult to fine-tune acts of intervention to the egalitarian element in some of the addressees. For what is adapted to them may be counterproductive for addressees adhering to different ways of life. Admittedly, part of the egalitarian problem with the Internet is the collateral empowerment of fatalists. They exploit a technology designed by egalitarians in line with their own way of life for unsocial fatalist behaviour. But improving the situation in this regard is also best done by targeting the egalitarians and inducing them to find better solutions for the Net architecture.

\section{b) Little Missionary Intent}

There are self-contained egalitarian movements. The Amish in the United States are a wellknown example. But history has many more examples of egalitarians who were missionary, if not fundamentalist. Such an aggressive trait makes balancing very demanding. Since such egalitarian actors are not willing to compromise in principle, the competing solidarities cannot but muster up countervailing power.

In the Internet case, the missionary element of egalitarians is at most weak. The typical Internet egalitarians are neither pro-hate speech, nor pro-child pornography. And only some of them oppose copyright on grounds of principle. Most would be content with the regimes in the off-line world. Individual copies for private use are permitted. But nobody is allowed to destroy the economic basis of the music industry by creating an alternative chain of distribution.

An additional advantage of this situation is on the side of the competing active solidarities. To the extent that Internet egalitarians are not missionary, the other solidarities need not fear losing their opportunities to live their own ways of life. Bringing co-existence between the different belief systems about is enough.

\section{The Tough Part}

Unfortunately, the list of features that make the rebalancing task tougher is much longer. Any governance attempt must target the Net architecture and the Net culture as such (section a below). While decontextualisation (section b) and the high speed of evolution (section c) are not particularly cumbersome, the weakening of sovereignty is (section d). It is frequently further 
compounded by a territorial mismatch (section e) and by the transcending of national cultures (section f). Finally, it is not so rare for Net egalitarians to be nested in other egalitarian movements that have different aims (section g).

\section{a) Governance of Net Architecture and Net Culture}

In the introduction, it has been demonstrated that and why the egalitarians have hardwired their way of life into the architecture of the Internet. Moreover, part of the social problem stems from the fact that fatalists have seized the opportunities created for them by this architecture. The rebalancing must thus have an impact on the architecture of the Internet if it is to be effective. This makes rebalancing more demanding. For the Internet, as it stands, has been purposefully created as a unitary medium. The rigorous standardization of some basic features opens up an almost unlimited space for use. The two basic features are the technical standard TCP/IP and the domain name system. The latter strictly couples a domain name with one IP address, or an exactly defined address space.

Economically speaking, the governance issue is thus characterized by indivisibility. This means that successful governance attempts must either partly make it divisible, or introduce elements from the other solidarities into these basic features of the Internet. The former is currently discussed under the heading of geographical filtering. This technology would artificially renationalise the Internet. ${ }^{280}$ Once in place, the same technology could also be used for building fences between groups of users adhering to different solidarities. The latter option would be taken if a successor standard to TCP/IP made individual Internet users identifiable. ${ }^{281}$

Ultimately, however, any technology is just a tool. The decisive question is how it is used. Specifically, as mentioned in the introduction, the music industry can already rely on technical tools to make illicit copying difficult. But all these copyright management systems are hacker prone. $^{282}$ In the end, only a general willingness to respect copyright can make it sustainable. ${ }^{283}$

\section{b) Decontextualisation}

In principle, the almost complete decontextualisation of Internet communication is the most severe challenge brought about by this medium. For society loses almost any opportunity to actualise social norms. Their erosion is likely. ${ }^{284}$ But this is not a problem with egalitarians. On the contrary, of any solidarity, they are likely to maintain social ties even in Internet communica-

280 More from GEIST in Berkeley Technology Law Journal (2001a) at notes 278 ss; BERMAN Internet and Nation State (2002) 66-69; REIDENBERG in Jurimetrics (2002) at notes $12 \mathrm{s.}$

281 This is what the debate over the standard Ipv6 centres around; see JAcoBus Taming the Web. Building Fences, One by One (2001)

282 Yu in FindLaw's Legal Commentary (2002).

283 Rightly pointed out by HARTWIG MASUCH, executive director of BMG UFA Musicpublishers, at the Cologne Popkomm fare, http://www.heise.de/newsticker/data/mw-17.08.02-007 (20.8.2002).

284 On the phenomenon in general see BOHNET Kooperation (1997) ; on its bearing on Internet governance see ENGEL The Role of Law in the Governance of the Internet (2002c) 
tion. For internally, they organise themselves through social ties. Put differently, decontextualisation makes it even more likely that the Internet architecture will empower fatalists. But, as mentioned repeatedly, any action undertaken to counter the growing fatalism must target the egalitarian designers and managers of the Net architecture.

\section{c) Speed of Evolution}

Thus far, the Internet has evolved at ultra high speed. This is precisely what the basic architecture of the Internet was designed for. Technically it should be as easy as possible to link ever more Networks to the Internet. And socially speaking, ever new appliances are mushrooming. For any governance attempt, the Internet is thus a moving target. Normatively speaking, the point is even stronger. For that very reason outsiders should carefully design their acts of intervention, given their own reliance on the evolutionary potential of the Internet.

These features call for the design of interventions with a high inbuilt flexibility. This does not exclude formal acts of intervention, like the intervention by law, or one relying on property rights. But all things being equal, less strict approaches are more promising.

\section{d) Weakened Sovereignty}

In the public opinion, the Internet epitomizes globalisation. The catchy term can mean many things. In this context, the pertinent interpretation is: it weakens sovereignty. Governments lose their governance monopoly. ${ }^{285}$ Those governed get more options for exit and voice. ${ }^{286}$ This affects hierarchical ways of rebalancing in particular. But to the extent that individualists cannot police the underlying institutions of their way of life themselves, their attempts at rebalancing are also affected. Threats to use sovereign powers are less credible. The luring of egalitarian actors, or their members, can also be affected. For it can become more difficult to make credible promises. This does not only hold for direct interventions, but also for contextual governance. For it can become more difficult to mould the context differently. This qualification presupposes, however, that the context is as globalised as the egalitarian target itself. This need not be so. Imposing a higher degree of corporatisation on egalitarian actors is also more cumbersome.

There are two important qualifications, however. The nation-state is not the only possible form of hierarchic governance. Several nation-states can join forces and write international treaties or create international organisations. Hierarchy can join forces with non-state actors, like multinational firms. For instance, the U.S. government is apparently trying to change the Internet architecture by exerting influence on hardware and software companies. And not all nation-states are equally affected. In particular, the U.S. might still be able to muster up enough resources to impose its will on those responsible for the evolution of the Internet architecture. 


\section{e) Territorial Mismatch}

A second interpretation of globalisation does not focus on the weakening of formal state authority. It rather stresses the fading territorial match between the nations as power centres and the governance issue. ${ }^{287}$ For implicitly, in the theoretical part of the paper, this territorial match has been assumed. The competing solidarities have been treated as if all of them were part of one and the same, well-defined society. Actually, though, this is less and less true in general, and for the Internet in particular. The political system, and thus formal hierarchy, still largely rests on the nation-states' power. Many sectors of the economy, however, reach further out. ${ }^{288}$ Likewise, the territorial reach of civil society frequently does not coincide with national territory. This is important for governing egalitarian movements if they are transnational. In political science jargon, they are then usually called non-governmental organisations. ${ }^{289}$

This territorial mismatch partly explains why sovereignty is weakened. But its impact goes beyond the exercise of formal state authority. If these actors, or many of their members, are not present on the local markets, luring or threatening them the commercial way is hard to do. If members are dispersed all over the world, it also becomes much more difficult to predict how egalitarianism will play itself out in the case at hand. And it is not easy to bring the conflict between the ways of life into a well-defined arena. Rather, the conflict will be across arenas, with differently composed conflict lines.

\section{f) Transcending National Culture}

A third, related element of globalisation is the possibility that the conflict among ways of life will transcend national cultures. Literally, the combatants might not speak the same language. This is even more important metaphorically. Since cognition is a social endeavour, it is perforce linked to a social background, i.e. to a culture. Even if egalitarians all over the world share some basic beliefs, they may well play themselves out quite differently, due to the embeddedness of the individuals in their home cultures. Outside actors thus have to face many more culturally contingent mixes of solidarities. The conflict is no longer one between different solidarities hinging upon one and the same national background culture. It is rather one between overlapping solidarities.

This element of globalisation will make it more difficult to pitch competing solidarities against the egalitarian group solidarity. For different members of the egalitarian movement will be responsive to different national solidarities. Likewise, it will become more difficult to exploit differences in egalitarian zeal among the members. For the characteristic features of zealots and followers will differ within the movement. Similarly, it is less easy to address multiple selves; for the elements of such multiplicities are much harder to predict.

287 For an insightful treatment see the introduction of SCHARPF Governing in Europe (1999) .

288 In the technical terms of antitrust law: the relevant geographical market is larger than the nation state.

289 For an overview of the rich literature see ARTS Non-State Actors in Global Governance. Three Faces of Power (2003) . 


\section{g) Nested Egalitarianism}

The theoretical part of the paper has assumed that there is just one egalitarian movement, and that its mission is nothing but Internet architecture. This is an obvious simplification. There are many different movements engaged in Internet governance issues. And many of them make more than just this issue their cause.

Such nested egalitarianism can create new opportunities for outside actors. For they gain extra access points from issue areas beyond the Internet. And they can go for a piecemeal approach, targeting the most responsive egalitarian movements first. But the nested character is also an additional challenge. To the extent that there is solidarity among egalitarian movements, they can give each other additional support to parry outside interventions. And it becomes more difficult to predict reactions ex ante.

\section{Tentative Normative Conclusions}

The specific features of the Internet case do not altogether disempower the options that would be available in the pure case, studied in the theoretical part of the paper. But these additional challenges may make it more attractive to use those options that remain almost unaffected by the additional challenges. All things being equal, informal strategies are more promising than formal ones. Constructivist approaches are less affected than rationalist ones. Contextual approaches are easier than direct acts of intervention.

Above all, in the specific case, hybrid solutions are even more attractive than in theory. ${ }^{290}$ Creative mixes of elements from different intellectual and normative backgrounds are the order of the day. By way of illustration, three such approaches shall be mentioned.

In the area of digital music distribution, the following fact finding mission has been proposed: the music industry has huge archives of recordings. It holds copyrights on them. But it neither sells them presently, nor does it expect future sales. The music labels could themselves set up an electronic library. It could offer these recordings in compressed format for download for a truly small price. If the claims of egalitarians are true, this should not only generate additional revenues from these payments. More importantly, a new demand for music should be generated that was not marketable before. ${ }^{291}$ Such ideas have at least met some response in the music industry. There have been offers for free downloads over a week. ${ }^{292}$ Another publishing house has offered

290 This is a frequent statement in the literature on Internet governance, see e.g. GREWLICH Governance in Cyberspace (1999); LiTAN in Duke Law Journal (2001) 1057; NATIONAL RESEARCH CounCIL Global Networks and Local Values (2002a)

291 IAN Internet Debacle (2002b)

292 In Europe called the Digital Download Day, http://www.heise.de/newsticker/data/wst-21.01.03-000 (23.1.2003). 
music partitions for free download. ${ }^{293}$ Market research has demonstrated that the scheme works reasonably well, in that it attracts additional demand. ${ }^{294}$

A second, entirely different approach is organisational. It attempts to bring a better balance about by inviting, or imposing, representatives from the competing solidarities to egalitarian actors. Of course, this presupposes some degree of corporatisation. For the representative cannot possibly speak to most members of an egalitarian movement individually. A similar approach has been successfully used by governments to make firms more responsive to environmental matters. In many countries, environmental law obliges firms to hire representatives for the environment in general, or for more specific issues like waste management or emissions control. ${ }^{295}$ To a degree, ICANN follows this model. It works under a charter from the U.S. government, thus guaranteeing hierarchical input. The at large representatives are meant to be the egalitarian component. And individualists get their share through the scheme for electronically settling disputes over cyber squatting. $^{296}$

The last example will not surprise any student of international relations. For this field specifically studies issues that transcend the problem-solving capacity of nation-states. It thus starts from the premise that a monopoly of governance is not within reach. Of course, there is power politics for the purpose. But it has left many social problems of the community of states unsolved. And anyhow, it is only at the disposal of a small number of states, when it comes to global issues. There are also certainly a long history of failed attempts at arguing. More surprising, however, are the stories of success. Spreading human rights is one of the best. ${ }^{297}$ In a process of arguing, none of the ways of life has to renounce its resources. But serious attempts at arguing offer a framework for overcoming stalemate. One should not expect clean solutions from that. But given the theoretical incompatibility of the normative starting points, balancing solidarities can never lead to clean results. What can be done via arguing, however, is that core issues of the other ways of life can be sorted out. A joint definition of the social problem will often turn out to be too daring. But on a meta level, the competing ways of life can strive to define areas where violent conflict is likely. Put differently, arguing could result in better institutionalising the conflict between ways of life. This would be a much better outcome than the current, progressive exacerbation.

293 http://www.whc.de/ (22.9.2003).

294 http://www.heise.de/newsticker/data/pmz-18.02.03-004 (20.2.2003); http://www.heise.de/newsticker/data/ anw-08.05.03-003/ (11.5.2003). Another compromise formula would have to be implemented by the legislator. It could allow free file swapping, but would impose a levy for non-commercial use. This proposal is further developed by NETANEL Impose a Noncommercial Use Levy to Allow Free P2P File-Swapping and Remixing (2002) . It closely resembles how German law treats Xerox copies from books for personal use. They are legal. But the manufacturers of Xerox machines must pay a levy.

295 More on the situation in German law from ENGEL in Immenga, Möschel and Reuter (1996)

296 The latter term denotes the abusive reservation of domain names that are identical, or that closely resemble, trade marks and names of firms. More on ICANN from MUELLER in info (1999); FROOMKIN in Duke Law Journal (2000); WEINBERG in Duke Law Journal (2000). But all these authors are rather critical. 


\section{References}

Albert, HANS (1978). Traktat über rationale Praxis. Tübingen, Mohr.

Arce, Daniel G. and Todd SAndler (2003). "An Evolutionary Game Approach to Fundamentalism and Conflict." Journal of Institutional and Theoretical Economics 159: 132-154.

ArendT, HannaH (1951). The Origins of Totalitarianism. New York,, Harcourt Brace.

ARTS, BAS J.M. (2003). Non-State Actors in Global Governance. Three Faces of Power. Preprints aus der Max-Planck-Projektgruppe Recht der Gemeinschaftsgüter Bonn 2003/4. http://www.mpp-rdg.mpg.de/pdf_dat/2003_4.pdf

BARTOw, AnN (2001). "Arresting Technology." Buffalo Intellectual Property Law Journal 1: 95121.

Bechtold, Stefan (2002). Vom Urheber- zum Informationsrecht. Implikationen des Digital Rights Management. München, Beck.

Becker, Gary Stanley (1976). The Economic Approach to Human Behavior. Chicago, University of Chicago Press.

Bender, Gunnar (1998). "Bavaria vs. Felix Somm. The Pornography Conviction of the Former CompuServe Manager." International Journal of Communications Law and Policy(1): 1-4.

Benkler, Yochai (1999). "Net Regulation. Taking Stock and Looking Forward." Colorado Law Review 71: 1203-1261.

Benkler, Yochai (2000). "Internet Regulation. A Case Study in the Problem of Unilateralism." European Journal of International Law 11: 171-185.

Berman, Paul Schiff (2000). "Cyberspace and the State Action Debate. The Cultural Value of Applying Constitutional Norms to "Private" Regulation." University of Colorado Law Review 71: 1263-1310.

Berman, Paul Schiff (2002). The Internet, the Nation-State, and the Social Meaning of Legal Jurisdiction

Bessen, James E. (2001). Open Source Software. Free Provision Of Complex Public Goods. http://papers.ssrn.com/paper.taf?abstract_id=278148

Birnhack, Michael and Niva Elkin-Koren (2003). The Invisible Handshake. The Reemergence of the State in the Digital Environment. SSRN_ID381020_code030320500.pdf

Bohner, Gerd (2001). Attitudes. Introduction to Social Psychology. Miles Hewstone und Wolfgang Stroebe. Oxford, Blackwell: 239-282. 
BOHNET, IRIS (1997). Kooperation und Kommunikation. Eine ökonomische Analyse individueller Entscheidungen. Tübingen.

Boulding, Kenneth E. (1987). "The Economics of Pride and Shame." Atlantic Economic Journal 15: 10-19.

Boyle, James (1997). "Foucault in Cyberspace. Surveillance, Sovereignty, and Hardwired Censors." University of Cincinnati Law Review 66: 177-205.

BREMER, KARSTEN (2002). "Radikal-politische Inhalte im Internet - Ist ein Umdenken erforderlich ?" Multimedia und Recht: 147-152.

Brugger, Winfried (1999). Liberalismus, Pluralismus, Kommunitarismus. Studien zur Legitimation des Grundgesetzes. Baden-Baden, Nomos.

Burmeister, JOACHIM (1993). "Verträge und Absprachen zwischen der Verwaltung und Privaten." Veröffentlichungen der Vereinigung der Deutschen Staatsrechtslehrer 52: 190-247.

Clarke, Roger A., Gillian Dempsey, et al. (2001). The Technical Feasibility of Regulating Gambling on the Internet. http://www.aic.gov.au/conferences/gambling/dempsey-clarke.pdf

Cornes, Richard and TodD SAndler (1996). The Theory of Externalities, Public Goods and Club Goods. Cambridge, Cambridge University Press.

Cowan, Robin, Paul A. DAvid, et al. (2000). "The Explicit Economics of Knowledge Codification and Tacitness." Industrial and Corporate Change 9: 211-253.

DAm, KenNeth W. (1999). "Self-Help in the Digital Jungle." Journal of Legal Studies 28: 393412.

DAVID, PAUl A. (1997). Understanding the Economics of QWERTY. The Necessity of History. Economic Growth in the Long Run. A History of Empirical Evidence III. Bart van Ark. Cheltenham, Elgar: 281-300.

David, Paul A. (2000). The Internet and the Economics of Network Technology Evolution. Understanding the Impact of Global Networks on Local Social, Political and Cultural Values. Christoph Engel und Kenneth H. Keller. Baden-Baden, Nomos: 39-71.

Dertouzos, Michael (1997). What Will Be. How the New World of Information will Change our Lives. San Francisco, Harper Edge.

Dickenberger, Dorothee, Gisla Gniech, et al. (1993). Die Theorie der psychologischen Reaktanz. Theorien der Sozialpsychologie I: Kognitive Theorien. Dieter Frey und Martin Irle. Bern, Huber: 243-274. 
Douglas, MARY (1982). Cultural Bias. In the Active Voice. Mary Douglas. London, Routledge: 183-254.

EAston, DAVID (1965). A Systems Analysis of Political Life. New York,, Wiley.

EgAn, PATRICK T. (1996). "Virtual Community Standards. Should Obscenity Law Recognize the Contemporary Standard of Cyberspace?" Suffolk University Law Review 30: 117-152.

EgeBerg, Morten (2002). An Organisational Approach to European Integration. What Organisation Tells us about System Transformation, Committee Governance and Commission Decision Making. ARENA Working Papers WP 02/19. http://www.arena.uio.no/

ENGEL, CHRISTOPH (1996). Regulierung durch Organisation und Verfahren. Festschrift für ErnstJoachim Mestmäcker. Ulrich Immenga, Wernhard Möschel und Dieter Reuter. BadenBaden, Nomos: 119-138.

ENGel, Christoph (1998). "Selbstregulierung im Bereich der Produktverantwortung." Staatswissenschaften und Staatspraxis 9: 535-591.

Engel, Christoph (2000). The Internet and the Nation State. Understanding the Impact of Global Networks on Local Social, Political and Cultural Values. Christoph Engel und Kenneth H. Keller. Baden-Baden, Nomos: 201-260.

Engel, Christoph (2001a). Die Grammatik des Rechts. Instrumente des Umweltschutzes im Wirkungsverbund. Hans-Werner Rengeling. Baden-Baden, Nomos: 17-49.

ENGEL, CHRISTOPH (2001b). "Offene Gemeinwohldefinitionen." Rechtstheorie 32: 23-52.

Engel, CHRISTOPH (2002a). Abfallrecht und Abfallpolitik. Baden-Baden, Nomos.

Engel, Christoph (2002b). Die soziale Funktion des Eigentums. Bericht zur Lage des Eigentums. Otto Depenheuer, Christoph Engel und Thomas von Danwitz. Berlin, Springer: 1-107.

Engel, Christoph (2002c). The Role of Law in the Governance of the Internet. Preprints aus der Max-Planck-Projektgruppe Recht der Gemeinschaftsgüter Bonn 2002/13. http://www.mpp-rdg.mpg.de/pdf_dat/2002_13.pdf

Engel, Christoph (2003a). "Causes and Management of Conflicts." Journal of Institutional and Theoretical Economics 159: 1-15.

ENGEL, CHRISTOPH (2003b). "Die Internet-Service-Provider als Geiseln deutscher Ordnungsbehörden. Eine Kritik der Verfügungen der Bezirksregierung Düsseldorf." Multimedia und Recht 6: Beilage 4, 1-35.

Engel, CHRISTOPH (2003c). "Modelling Fundamentalism." Journal of Institutional and Theoretical Economics 159: 163-170. 
Etzioni, Amitai (1998). The Essential Communitarian Reader. Lanham, Md., Rowman \& Littlefield.

FARBER, DANIEL J. (2000). Predicting the Unpredictable - Technology and Society. Understanding the Impact of Global Networks on Local Social, Political and Cultural Values. Christoph Engel und Kenneth H. Keller. Baden-Baden, Nomos: 29-38.

FARNSWORTH, WARD (2003). The Legal Management of Self-Serving Bias

Festinger, LeON (1957). A Theory of Cognitive Dissonance. Evanston, Ill., Row Peterson.

Fowler, Brendon, Cara Franklin, et al. (2001). "Can you Yahoo!? The Internet's Digital Fences." Duke Law and Technology Review: 0012.

FOX, DIRK (2001). Technische Systeme zur Gewährleistung von Jugendschutz im Internet. Allianz von Medienrecht und Informationstechnik ? Ordnung in digitalen Medien durch Gestaltung der Technik am Beispiel von Urheberrechtsschutz, Datenschutz, Jugendschutz und Vielfaltschutz. Alexander Roßnagel. Baden-Baden, Nomos: 79-90.

Frey, Bruno and Felix Oberholzer-Gee (1999). Natural Environment. Fair Siting Procedures. Economics as a Science of Human Behaviour. Bruno Frey. Boston: 23-48.

FREY, BRUnO S. (1999). Economics as a Science of Human Behaviour. Towards a New Social Science Paradigm. Boston ; Dordrecht, Kluwer Academic Publishers.

Froomkin, A. Michael (1996). "Flood Control on the Information Ocean. Living With Anonymity, Digital Cash, and Distributed Databases." University of Pittsburgh Journal of Law and Commerce 15: 395-507.

Froomkin, A. Michael (2000). "Wrong Turn in Cyberspace. Using ICANN to Route Around the APA and the Constitution." Duke Law Journal 50: 17-186.

Furubotn, EIRIK GRUNDTVIG and RUdOLF Richter (1997). Institutions and Economic Theory. The Contribution of the New Institutional Economics. Ann Arbor, University of Michigan Press.

Geist, Michael A. (2001a). "Is There a There There? Toward Greater Certainty for Internet Jurisdiction." Berkeley Technology Law Journal 16: 1345-1406.

Geist, Michael A. (2001b). "The Legal Implications of the Yahoo! Inc. Nazi Memorabilia Dispute." Juriscom: January/March.

Giddens, ANTHONY (1984). The Constitution of Society. Outline of the Theory of Structuration. Berkeley, University of California Press. 
Gigerenzer, Gerd (2000). How to Make Cognitive Illusions Disappear. Adaptive Thinking. Rationality in the Real World. Gerd Gigerenzer. Oxford, Oxford University Press: 241-266.

Gigerenzer, Gerd, Ulrich Hoffrage, et al. (1991). "Probabilistic Mental Models. A Brunswikian Theory of Confidence." Psychological Review 98: 506-528.

Gigerenzer, Gerd, Peter M. Todd, et al. (1999). Simple Heuristics that Make us Smart. New York, Oxford University Press.

GolDSMITH, JACK (1998). "Against Cyberanarchy." University of Chicago Law Review 65: 1199-1250.

Granovetter, Marc (1985). "Economic Action and Social Structure. The Problem of Embeddedness." American Journal of Sociology 91: 481-510.

Grewlich, Klaus W. (1999). Governance in "Cyberspace". Access and Public Interest in Global Communications. The Hague ; Boston, Kluwer Law International.

Gruter, Margaret and Roger D. Masters, Eds. (1986). Ostracism. A Social and Biological Phenomenon. New York, Elsevier.

Gupta, AloK, Dale O. Stahl, et al. (1997). The Internet: A Future Tragedy of the Commons? Computational Approaches to Economic Problems. Hans Rustem Amman und Andrew Berc Whinston. Dordrecht, Kluwer: 347-361.

HAMBridGe, SAlly (1995). Netiquette Guidelines. http://www.cybernothing.org/cno/docs/ rfc1855.html

Hardin, Garrett (1968). "The Tragedy of the Commons." Science 162: 1243-1248.

Henrich, Joseph and Robert Boyd (2001). 'Economic Man' in Cross-Cultural Perspective. Behavioral Experiments in 15 Small-Scale Societies

Hirschman, Albert O. (1970). Exit, Voice, and Loyalty. Responses to Decline in Firms, Organizations, and States. Cambridge, Mass.,, Harvard University Press.

Holtgrewe, Ursula (2001). Kreativität als Norm - zum Erfolg verdammt? Open-Source Software zwischen sozialer Bewegung und technischer Innovation. Gute Gesellschaft? Verhandlungen des 30. Kongresses der Deutschen Gesellschaft für Soziologie in Köln 2000. Jutta Allmendinger. Opladen, Leske + Budrich: 399-424.

Holzinger, Katharina (2003). Transnational Common Goods. Strategic Constellations, Collective Action Problems, and Multi-Level Provision. 
Holznagel, Bernd (2002). "Meinungsfreiheit oder Free Speech im Internet. Unterschiedliche Grenzen tolerierbarer Meinungsäußerungen in den USA und Deutschland." Archiv für Presserecht 33: 128-133.

Holznagel, Bernd and Stephanie Kussel (2001). "Möglichkeiten und Risiken bei der Bekämpfung rechtsradikaler Inhalte im Internet." Multimedia und Recht: 347-352.

Hunter, Dan (2002). Cyberspace as Place, and the Tragedy of the Digital Anticommons. http://papers.ssrn.com/paper.taf?.abstract_id=306662

IAN, JANIS (2002a). Fallout. http://www.janisian.com/article-fallout.html

IAN, JANIS (2002b). The Internet Debacle - An Alternative View.

http://www.janisian.com/article-internet_debacle.html

Jacobus, PAtricia (2001). Taming the Web. Building Fences, One by One.

http://news.com.com/2009-1023-255774-2.html

JAKOBS, GÜNTHER (1999). Norm, Person, Gesellschaft. Vorüberlegungen zu einer Rechtsphilosophie. Berlin, Duncker \& Humblot.

Kahneman, Daniel, Paul Slovic, et al. (1982). Judgment under Uncertainty. Heuristics and Biases. Cambridge ; New York, Cambridge University Press.

Kalathil, Shanthi and TAYlOR C. BoAs (2001). The Internet and State Control in Autoritarian Regimes. China, Cuba, and the Counterrevolution. Carnegie Endowment of International Peace Working Paper 21

Katzenbeisser, Stefan and Fabien A. P. Petitcolas, Eds. (2000). Information Hiding Techniques for Steganography and Digital Watermarking. Artech House computer security series. Boston, Artech House.

KeLly, Kevin (1998). New Rules for the New Economy. 10 Radical Strategies for a Connected World. New York, N.Y., Viking.

Kelman, Mark, Yuval Rottenstreich, et al. (2000). Context-Dependence in Legal Decision Making. Behavioural Law and Economics. Cass R. Sunstein. Cambridge, Cambridge University Press: 61-94.

Kennedy, Charles H. and Peter Swire (2003). State Wiretaps and Electronic Surveillance After September 11. SSRN_ID416586_code030718500.pdf

Kesan, Jay P. and Andres A. Gallo (2001). Neither Bottom-Up Nor Top-Down. A Tacit Public-Private Cooperative Solution for Internet Regulation 
Kesan, Jay P. and Rajiv C. Shah (2001). "Fool us Once Shame on You- Fool UsTwice Shame on Us: What We Can Learn from the Privatizations of the Internet Backbone Network and the Domain Name System." Washington University Law Quarterly 79: 89-220.

KNIGHT, JACK (1992). Institutions and Social Conflict. Cambridge England ; New York, N.Y., Cambridge University Press.

Koch, ARnd (2002). "Zur Strafbarkeit der "Auschwitzlüge" im Internet - BGHSt 46, 212." Juristische Schulung: 123-127.

KÖHNTOPP, KRISTIAN, MARIT KÖHNTOPP, et al. (1998). "Sperrungen im Internet. Eine systematische Aufarbeitung der Zensurdiskussion." Kommunikation und Recht 1: 25-32.

Kollock, Peter and Marc Smith (1996). Managing the Virtual Commons. Cooperation and Conflict in Computer Communities. Computer-Mediated Communication. Lingustic, Social and Cross-Cultural Perspectives. Susan Herring. Amsterdam, John Benjamins: 109-128.

KREBS, WALter (1993). "Verträge und Absprachen zwischen der Verwaltung und Privaten." Veröffentlichungen der Vereinigung der Deutschen Staatsrechtslehrer 52: 248-284.

Ku, Raymond ShiH Ray (2002). "The Creative Destruction of Copyright. Napster and the New Economics of Digital Technology." University of Chicago Law Review 69: 263-324.

KuAn, Jennifer W. (2001). Open Source Software as Consumer Integration Into Production. http://papers.ssrn.com/paper.taf?abstract_id=259648

KÜBLER, FRIEDRICH (2000). "Äußerungsfreiheit und rassistische Propaganda. Grundrechtskonflikte im Zugwind der Globalisierung." Sitzungsberichte der Wissenschaftlichen Gesellschaft an der Johann Wolfgang Goethe-Universität Frankfurt am Main 37: 149-188.

KurAn, TIMOR (1989). "Sparks and Prairie Fires. A Theory of Unanticipated Political Revolution." Public Choice 6: 41-74.

Laland, Kevin N. and Gillian R. Brown (2002). Sense and Nonsense. Evolutionary Perspectives on Human Behaviour. Oxford ; New York, Oxford University Press.

LEMAIRE, JeAn-RAYMOND (2001). Filtering Techniques and Methods

LeRner, Josh and JeAn Tirole (2000). The Simple Economics of Open Source. National Bureau of Economic Research Working Paper 7600. http://papers.ssrn.com/paper.taf?abstract_id=224008

LeSSig, LAWRENCE (1999). Code and other Laws of Cyberspace. New York, Basic Books.

Lessig, Lawrence and Paul Resnick (1999). "Zoning Speech on the Internet. A Legal and Technical Model." Michigan Law Review 98: 395-431. 
LitAn, Robert E. (2001). "Law and Policy in the Age of the Internet." Duke Law Journal 50: 1045-1085.

Livesey, S.M. (1999). "McDonald's and the Environmental Defense Fund. A Case Study of a Green Alliance." Journal of Business Communication 36: 5-39.

LÜBBE-WOLFF, GERTRUDE (1996). Modernisierung des Umweltordnungsrechts. Vollziehbarkeit - Deregulierung - Effizienz. Bonn, Economica.

LuHMANn, NiKLAS (1986). Ökologische Kommunikation. Kann die moderne Gesellschaft sich auf ökologische Gefährdungen einstellen? Opladen, Westdeutscher Verlag.

Luhmann, NikLas (1995). "Einige Probleme mit "Reflexivem Recht"." Zeitschrift für Rechtssoziologie 6: 1-18.

Majone, Giandomenico (2001). "Nonmajoritarian Institutions and the Limits of Democratic Governance. A Political Transaction-Cost Approach." Journal of Institutional and Theoretical Economics 157: 57-78.

MARCh, James G. and Johan P. OlSEN (1989). Rediscovering Institutions. The Organizational Basis of Politics. New York, Free Press.

MARch, James G. and Johan P. Olsen (1998). "The Institutional Dynamics of International Political Orders." International Organization 52: 943-969.

Mayer, Franz C. (2000). "Europe and the Internet. The Old World and the New Medium." European Journal of International Law 11: 149-169.

MAYntZ, RenATE (1980). Implementation politischer Programme. Empirische Forschungsberichte. Königstein/Ts., Verlagsgruppe Athenäum Hain Scriptor Hanstein.

Mayntz, Renate (1983). Implementation von regulativer Politik. Implementation politischer Programme II. Renate Mayntz. Opladen, Westdeutscher Verlag: 50-74.

MCGOWAN, DAVID (2001). "Legal Implications of Open-Source Software." University of Illinois Law Review: 241-304.

Mueller, Milton (1999). "ICANN and Internet Governance. Sorting Through the Debris of 'Self-Regulation'." info 1: 497-520.

Mueller, Milton (2002). Ruling the Root. Internet Governance and the Taming of Cyberspace. Cambridge, Mass., MIT Press.

MÜLLER, LORENZ (2002). Elektronisches Geld. Baden-Baden, Nomos.

Nachbar, Thomas B. (2000). "Paradox and Structure. Relying on Government Regulation to Preserve the Internet's Unregulated Character." Minnesota Law Review 85: 215-318. 
NASH, JoHn (1950). "The Bargaining Problem." Econometrica 18: 155-162.

NASH, JoHN (1951). "Non-Cooperative Games." Annals of Mathematics 54: 286-295.

NAtional Research Council (1996). Cryptography's Role in Securing the Information Society. Washington, National Academy.

National Research Council (2002a). Global Networks and Local Values. Washington, National Academy of Sciences.

National Research Council (2002b). Youth, Pornography, and the Internet. Washington, National Academy Press.

Netanel, NeIL W. (2002). Impose a Noncommercial Use Levy to Allow Free P2P FileSwapping and Remixing. University of Texas Public Law Research Paper 44. SSRN_ID352560_code021130630.pdf

Neumann, Franz Leopold (1942). Behemoth. The Structure and Practice of National Socialism. Toronto, New York etc., Oxford university press.

Olson, Mancur (1965). The Logic of Collective Action. Public Goods and the Theory of Groups. Cambridge, Mass., Harvard University Press.

O'NeILl, BARRY (2003). "Mediating Conflicts over Honour. Lessons from the Era of Dueling." Journal of Institutional and Theoretical Economics 159: 229-247.

Ostrom, ElinOR (1990). Governing the Commons. The Evolution of Institutions for Collective Action. Cambridge ; New York, Cambridge University Press.

Ostrom, Elinor, Thomas Dietz, et al., Eds. (2002). The Drama of the Commons. Washington, National Academy Press.

Penfold, Carolyn (2001). "Nazis, Porn and Politics. Asserting Control Over Internet Content." Journal of Information, Law and Technology(2).

Perritt, Henry H. (1997). "Cyberspace Self-Government. Town Hall Democracy or Rediscovered Royalism?" Berkeley Technology Law Journal 12: 413-482.

Pessach, GuY (2003). Copyright Law as a Silencing Restriction on Non-Infringing Materials Unveiling the Real Scope of Copyright's Diversity Externalities. Yale Law \& Economics Research Paper 268. SSRN_ID354420_code030915570.pdf

Pigou, A. C. (1932). The Economics of Welfare. London,, Macmillan and co. limited.

Posner, ERIC A. (2003). "Four Economic Perspectives on American Labor Law and the Problem of Social Conflict." Journal of Institutional and Theoretical Economics 159: 101-116. 
Rachlinski, Jeffrey J. (2000). A Positive Psychological Theory of Judging in Hindsight. Behavioral Law and Economics. Cass R. Sunstein. Cambridge, Cambridge University Press: 95-115.

RADin, MARgaret Jane (1987). "Market-Inalienability." Harvard Law Review 100: 1849-1937.

Radin, Margaret Jane and R. Polk Wagner (1998). "The Myth of Private Ordering. Rediscovering Legal Realism in Cyberspace." Chicago Kent Law Review 73: 1295-1317.

Reddy, Bernard and David S. Evans (2002). Government Preferences for Promoting OpenSource Software. A Solution in Search of a Problem. http://papers.ssrn.com/paper.taf?abstract_id=313202

ReidenBerg, Joel (1996). "Governing Networks and Rule-Making in Cyberspace." Emory Law Journal 45: 911-930.

Reidenberg, Joel (1998). "Lex Informatica. The Formulation of Information Policy Rules Through Technology." Texas Law Review 76: 553-593.

ReidenBerg, Joel (2002). "Yahoo and Democracy on the Internet." Jurimetrics 42.

Risse, Thomas (1999). "International Norms and Domestic Change. Arguing and Communicative Behaviour in the Human Rights Area." Politics \& Society 27: 529-559.

Risse, Thomas (2000). "'Let's Argue!". Communicative Action in World Politics." International Organization 54: 1-39.

Risse, Thomas, Anja Jetschke, et al. (2002). Die Macht der Menschenrechte. Internationale Normen, kommunikatives Handeln und politischer Wandel in den Ländern des Südens. Baden-Baden, Nomos.

Rousseau, JeAN-JACQUes (1763). Du contrat social; ou, Principes du droit politique. n.p.

SCHÄFER, WOLF (1999). Globalisierung: Entmonopolisierung des Nationalen ? Globalisierung der Wirtschaft. Ursachen - Formen - Konsequenzen. Hartmut Berg. Berlin: 9-21.

Scharpf, Fritz Wilhelm (1997). Games Real Actors Play. Actor-centered Institutionalism in Policy Research. Boulder, Colo., Westview Press.

SCHARPF, Fritz WilHELm (1999). Governing in Europe. Effective and Democratic? Oxford ; New York, Oxford University Press.

Scheff, Thomas J. (2000). "Shame and the Social Bond: A Sociological Theory." Sociological Theory 18: 84-99.

SCHLICHT, EKKEHART (1998). On Custom in the Economy. Oxford, Clarendon Press. 
SCHMIDT, KARSTEN (2002). Gesellschaftsrecht. Köln, Heymanns.

Schmitter, Philippe C. and Wolfgang Streeck (1999). The Organization of Business Interests. Studying the Associative Action of Business in Advanced Industrial Societies. MaxPlanck-Institut für Gesellschaftsforschung Discussion Paper 99/1

Schwarz, Joel Michael (1999). "The Internet Gambling Fallacy Craps Out." Berkeley Technology Law Journal 14: 1021-1070.

Shapiro, Michael (1988). "Introduction: Judicial Selection and the Design of Clumsy Institutions." Southern California Law Review 61: 1555-1569.

SIEBER, UlRICH (1997). "Kontrollmöglichkeiten zur Verhinderung rechtswidriger Inhalte in Computernetzen. Zur Umsetzung von § 5 TDG am Beispiel der Newsgroups des Internet." Computer \& Recht: 581-598 und 653-669.

SIEBER, UlRICH (1999). Verantwortlichkeit im Internet. Technische Möglichkeiten und multimediarechtliche Regelungen. Zugleich eine Kommentierung von $\S 5$ TDG und $\S 5$ MDStV. München, Beck.

Sieber, Ulrich (2001). "Die Bekämpfung von Hass im Internet. Technische, rechtliche und strategische Grundlagen für ein Präventivkonzept." Zeitschrift für Rechtspolitik 34: 97-103.

SiegenthaleR, HANSJÖRG (1993). Regelvertrauen, Prosperität und Krisen : die Ungleichmässigkeit wirtschaftlicher und sozialer Entwicklung als Ergebnis individuellen Handelns und sozialen Lernens. Tübingen, J.C.B. Mohr (Paul Siebeck).

SMEND, Rudolf (1968). Verfassung und Verfassungsrecht. Staatsrechtliche Abhandlungen und andere Aufsätze. Rudolf Smend. Berlin, Duncker \& Humblot: 119-276.

Smith, AdAm (1790). The Theory of Moral Sentiments, or, An Essay Towards an Analysis of the Principles by which Men Naturally Judge Concerning the Conduct and Character, First of Their Neighbours, and Afterwards of Themselves. To which is Added, a Dissertation on the Origin of Languages. London, Strahan.

Sunstein, CAss R. (1995). "Incompletely Theorized Agreements." Harvard Law Review 108: 1733-1772.

Tesfatsion, Leigh (2001). "Introduction to the Special Issue on Agent-Based Computational Economics." Journal of Economic Dynamics and Control 25: 281-293.

Teubner, Gunther (1982). "Reflexives Recht. Entwicklungsmodelle des Rechts in vergleichender Perspektive." Archiv für Rechts- und Sozialphilosophie 68: 13-59.

Teubner, GunTHER (1989). Recht als autopoietisches System. Frankfurt, Suhrkamp. 
ThOMPSON, M., Richard ELLIS, et al. (1990). Cultural Theory. Boulder, Colo., Westview Press.

ThOMPSON, Michael (2000). Global Networks and Local Cultures. What are the Mismatches and What Can be Done About them ? Understanding the Impact of Global Networks on Local Social, Political and Cultural Values. Christoph Engel und Kenneth H. Keller. Baden-Baden, Nomos: 119-134.

Tirole, JEAN (1988). The Theory of Industrial Organization. Cambridge, Mass., MIT Press.

Trachtman, Joel P. (1998). "Cyberspace, Sovereignty, Jurisdiction and Modernism." Indiana Journal of Global Legal Studies 5: 561-582.

Tranvik, Tommy, Michael Thompson, et al. (2000). Doing Technology (and Democracy) the Pack-Donkey's Way. The Technomorphic Approach to ICT Policy. Governance of Global Networks in the Light of Differing Local Values. Christoph Engel und Kenneth H. Keller. Baden-Baden, Nomos: 155-195.

Trenholm, Sarah (1989). Persuasion and Social Influence. Englewood Cliffs, N.J., Prentice Hall.

TURner, MARK (2001). Cognitive Dimensions of Social Science. New York, Oxford University Press.

VAn WiJK, Jeroen (2002). Dealing With Piracy. Intellectual Asset Management in Music and Software. ERIM Report Series 2002/86. SSRN-erimrs20020930173203.pdf

VAnBerg, Victor and JAmes M. Buchanan (1989). "Interests and Theories in Constitutional Choice." Journal of Theoretical Politics 1: 49-62.

VASSILAKI, IRINI E. (2001). "Anmerkung [zu BGH 12.12.2000 - Auschwitzlüge]." Computer \& Recht: 262-265.

VerweiJ, Marco (2001). A Snowball against Global Warming. An Alternative to the Kyoto Protocol. Preprints aus der Max-Planck-Projektgruppe Recht der Gemeinschaftsgüter Bonn 2001/11. http://www.mpp-rdg.mpg.de/pdf_dat/2001_11.pdf

WALDEnBerger, ARTHUR (2000). Verbraucherschutz im Internet. Multimediarecht. Thomas Hoeren und Ulrich Sieber. München, Beck: Kap. 13.4.

WEGNER, GERHARD (1996). Wirtschaftspolitik zwischen Selbst- und Fremdsteuerung - ein neuer Ansatz. Baden-Baden, Nomos.

Weinberg, Jonathan (1997). "Rating the Net." Hastings Communications and Entertainment Law Journal 19: 453-482. 
WeinBerg, JonAthan (2000). "ICANN and the Problem of Legitimacy." Duke Law Journal 50: 187-260.

White, HARrison C. (1992). Identity and Control. A Structural Theory of Social Action. Princeton, N.J., Princeton University Press.

Williamson, Oliver E. (1985). The Economic Institutions of Capitalism. Firms, Markets, Relational Contracting. New York London, Free Press ; Collier Macmillan.

Willke, Helmut (1983). Die Entzauberung des Staates. Überlegungen zu einer sozietalen Steuerungstheorie. Frankfurt, Athenäum.

WinTER, GerD (1975). Das Vollzugsdefizit im Wasserrecht. Ein Beitrag zur Soziologie des Öffentlichen Rechts. Berlin, Schmidt.

Yee, Albert S. (1996). "The Causal Effects of Ideas on Policies." International Organization 50: 66-108.

Yu, Peter K. (2002). "How the Motion Picture and Recording Industries are Losing the Copyright War by Fighting Misdirected Battles." FindLaw's Legal Commentary: Aug. 15, 2002.

YU, PETER K. (2003). The Escalating Copyright Wars. SSRN_ID436693_code030821630.pdf

YurciK, William and ZiXiang TAN (1996). The Great (Fire)Wall of China. Internet Security and Information Policy Issues in the People's Republic of China.

http://www.tprc.org/abstracts/tan.txt

Zittrain, Jonathan (2003). Internet Points of Control. Harvard Law School, Public Law Working Paper 54.

http://papers.ssrn.com/sol3/delivery.cfm/SSRN_ID388860_code030319570.pdf?abstractid $=388860$ 